\title{
Porewater Carbonate Chemistry Dynamics in a Temperate and a Subtropical Seagrass System
}

\author{
Theodor Kindeberg 1,2,3 (D) Nicholas R. Bates ${ }^{4,5} \cdot$ Travis A. Courtney $^{1} \cdot$ Tyler Cyronak $^{1,7}$. \\ Alyssa Griffin ${ }^{1} \cdot$ Fred T. Mackenzie ${ }^{6} \cdot$ May-Linn Paulsen ${ }^{1} \cdot$ Andreas J. Andersson ${ }^{1}$
}

Received: 13 December 2018 / Accepted: 1 May 2020 / Published online: 16 May 2020

(c) The Author(s) 2020

\begin{abstract}
Seagrass systems are integral components of both local and global carbon cycles and can substantially modify seawater biogeochemistry, which has ecological ramifications. However, the influence of seagrass on porewater biogeochemistry has not been fully described, and the exact role of this marine macrophyte and associated microbial communities in the modification of porewater chemistry remains equivocal. In the present study, carbonate chemistry in the water column and porewater was investigated over diel timescales in contrasting, tidally influenced seagrass systems in Southern California and Bermuda, including vegetated (Zostera marina) and unvegetated biomes $(0-16 \mathrm{~cm})$ in Mission Bay, San Diego, USA and a vegetated system (Thallasia testudinium) in Mangrove Bay, Ferry Reach, Bermuda. In Mission Bay, dissolved inorganic carbon (DIC) and total alkalinity (TA) exhibited strong increasing gradients with sediment depth. Vertical porewater profiles differed between the sites, with almost twice as high concentrations of DIC and TA observed in the vegetated compared to the unvegetated sediments. In Mangrove Bay, both the range and vertical profiles of porewater carbonate parameters such as DIC and TA were much lower and, in contrast to Mission Bay where no distinct temporal signal was observed, biogeochemical parameters followed the semi-diurnal tidal signal in the water column. The observed differences between the study sites most likely reflect a differential influence of biological (biomass, detritus and infauna) and physical processes (e.g., sediment permeability, residence time and mixing) on porewater carbonate chemistry in the different settings.
\end{abstract}

Keywords Carbonate chemistry $\cdot$ Carbon cycling $\cdot$ Estuarine processes $\cdot$ Blue carbon · Ocean acidification $\cdot$ Sediment $\cdot$ Early diagenesis $\cdot$ Interstitial water

Electronic supplementary material The online version of this article (https://doi.org/10.1007/s 1049 8-020-09378-8) contains supplementary material, which is available to authorized users.

Theodor Kindeberg

theo.kindeberg@gmail.com

Extended author information available on the last page of the article 


\section{Introduction}

Coastal ecosystems play an important role in the global carbon cycle, largely due to the lateral transport of carbon and nutrients from rivers, terrestrial runoff and groundwater, intense benthic and pelagic metabolism and carbon transformation pathways in biomes such as seagrass beds, coral reefs, kelp forests, wetlands and saltmarshes (Duarte et al. 2005; Bauer et al. 2013). Seagrass beds are among the most productive marine ecosystems on Earth, trapping and storing a significant amount of carbon in their biomass and underlying soil (Duarte et al. 2005; Fourqurean et al. 2012; Mazarrasa et al. 2015). This makes seagrass an important contributor to what is known as blue carbon, or the ability of marine plants and ecosystems to help mitigate climate change by sequestering and storing anthropogenic $\mathrm{CO}_{2}$ (Nellemann et al. 2009; Fourqurean et al. 2012; Mazarrasa et al. 2015; Howard et al. 2017). In addition to this important ecosystem service, seagrass beds also modify their surrounding seawater chemistry through the processes of photosynthesis and respiration. Several studies have proposed that seagrass beds are not only significant carbon sinks, but also provide a local buffering effect against ocean acidification (OA) and may act as refugia for marine species that are sensitive to lowered $\mathrm{pH}$ (Burdige and Zimmerman 2002; Barron et al. 2006; Semesi et al. 2009; Unsworth et al. 2012; Hendriks et al. 2014; Camp et al. 2016; Delgard et al. 2016; Cyronak et al. 2018a; Pacella et al. 2018).

Previous studies investigating the influence of seagrass on water column carbonate chemistry have predominantly focused on aboveground productivity whereas biogeochemical processes occurring in the underlying sediment have received far less attention (Delgard et al. 2016). Several studies have shown that porewater processes can play a significant part in modifying the overlying water column chemistry, which can be further amplified in the presence of seagrass (Burdige and Zimmerman 2002; Burdige et al. 2008; Deborde et al. 2008; Migné et al. 2016). For example, Burdige et al. (2002, 2008) showed that seagrass enhances carbonate sediment dissolution by fueling high rates of organic matter (OM) remineralization in the sediments by pumping oxygen via their roots and rhizomes that subsequently leads to elevated $\mathrm{CO}_{2}$, lower carbonate saturation state $(\Omega)$ and elevated rates of carbonate mineral dissolution. These authors also proposed that the alkalinity generated from carbonate sediment dissolution in seagrass beds could constitute a negative feedback mechanism to increasing atmospheric $\mathrm{CO}_{2}$ (Burdige and Zimmerman 2002; Burdige et al. 2008). Regardless of whether this is the case or not, the mechanism of transporting photosynthetically derived oxygen downward from shoots to roots (Smith et al. 1984; Caffrey and Kemp 1991; Borum et al. 2007) can have a significant influence on both porewater and water column chemistry. The release of oxygen into the sediments, known as radial oxygen loss (ROL), exerts a strong localized effect on the porewater chemistry surrounding the roots and rhizomes (Sand-Jensen et al. 1982; Borum et al. 2007). By inducing aerobic remineralization of OM, anaerobic redox processes are limited and reduced species are oxidized which lowers $\mathrm{pH}$ and consumes total alkalinity (TA) (Lee and Dunton 2000; Burdige and Zimmerman 2002; Brodersen et al. 2016). It is, however, not clear what the spatial extent of the oxygen release is and if it has implications for the biogeochemical processes farther than a few millimeters away from the roots (Greve et al. 2003; Ingemann Jensen et al. 2005; Frederiksen and Glud 2006; Brodersen et al. 2018). In addition to affecting oxygen levels, it has also been reported that seagrasses can utilize $\mathrm{CO}_{2}$ from the porewater by transporting it to their shoots to sustain photosynthesis (Invers et al. 2001; Winkel and Borum 2009). Delgard et al. (2016) attributed this process to observations of net consumption of dissolved inorganic carbon (DIC) in porewaters underlying Zostera noltii beds 
compared to adjacent unvegetated sediments which exhibited a net production of DIC. However, no measurement of diel variability in porewater DIC was carried out and it is therefore unknown to what extent this tentative process is modifying porewater carbonate chemistry (Delgard et al. 2016).

Regardless of the presence of vegetation, the relative production and consumption of DIC and TA in porewaters are largely governed by the early diagenetic processes in the sediment (Fig. 1; Krumins et al. 2013). Strong porewater gradients of DIC and TA are often observed in marine sediments, and concentrations typically increase with sediment depth as a result of aerobic and anaerobic mineralization processes (Mucci et al. 2000; Jourabchi et al. 2005; Rassmann et al. 2016).

However, it is not well known how porewater biogeochemistry changes over diel time scales and how local features such as tidal regime and sediment properties may interact with the presence of seagrass. Several studies from mangrove environments have reported tidally driven porewater fluxes which strongly influence the chemistry of overlying waters (e.g., Bouillon et al. 2007; Sippo et al. 2016; Tait et al. 2016; Taillardat et al. 2018). For instance, Taillardat et al. (2018) showed that a mangrove-dominated tidal creek was heavily influenced by porewater pumping during ebb tide, in which the mangrove porewaters contributed $46 \pm 14 \%$ to increases in water column DIC. However, to the best of our knowledge, a complete characterization of diurnal variability of porewater carbonate chemistry in sediments colonized by seagrass has not been described in the literature.

Considering the role of coastal sediments and seagrass systems in marine biogeochemical cycles and dynamics, it is necessary to understand all parts of a seagrass ecosystem and

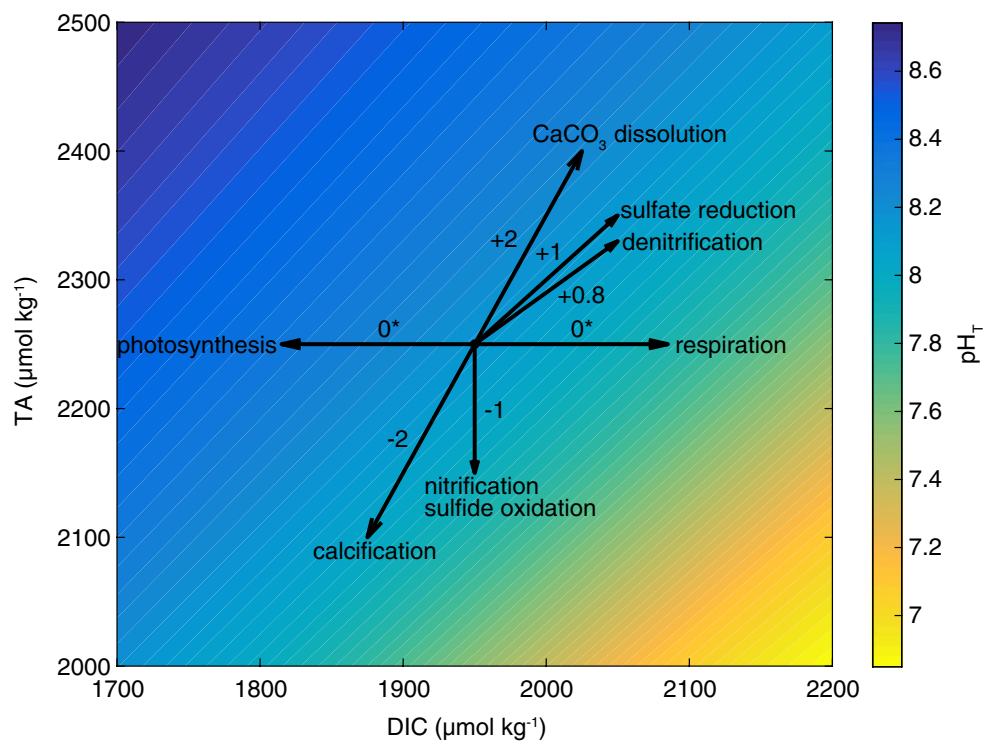

Fig. 1 Conceptual property-property plot of TA and DIC with $\mathrm{pH}_{\mathrm{T}}$ isopleths. Arrows indicate sediment carbon chemistry and redox processes and their respective effect on DIC, TA and $\mathrm{pH}_{\mathrm{T}}$. Slopes (positive numbers) are based on the stoichiometry of equilibrium reactions from Krumins et al. (2013) (redox reactions) and Andersson et al. (2014) (carbonate chemistry processes), while negative numbers represent the change in TA per mole $\mathrm{O}_{2}$ consumed or mole $\mathrm{CaCO}_{3}$ produced. The asterisk denotes that photosynthesis and respiration have a minor effect on TA $\left( \pm 0.14\right.$ assuming Redield stoichiometry). $\mathrm{pH}_{\mathrm{T}}$ values are calculated using constant temperature $\left(20^{\circ} \mathrm{C}\right)$, salinity $(34)$ and pressure $(0$ bar) and do not account for variation in redox conditions 
its interplay with the surrounding environment. From an OA perspective, it is of particular interest to better understand how biogeochemical processes in the sediments modify carbonate chemistry in both the porewater and the overlying bottom water as this provides insights to the present-day conditions experienced by organisms (e.g., Rassmann et al. 2018). This includes improving our understanding and quantification of the role of seagrasses for sediment biogeochemistry, and constraining the physical, chemical and biological drivers of their spatial and temporal variability (Burdige 2006; Lessin et al. 2018; Middelburg 2018). The aim of this study was to elucidate the difference in carbonate chemistry parameters between the sediment porewater in contrasting seagrass environments in Mission Bay (San Diego, USA), representing a temperate, heavily modified estuary comprised of siliciclastic mud and a mangrove embayment in Mangrove Bay (Ferry Reach, Bermuda), representing a less altered, subtropical, carbonate sediment environment. At both locations, porewaters were sampled within the seagrass bed, while in Mission Bay samples were also taken from bare sediments without any aboveground seagrass vegetation. Our goal was to examine the following questions: (i) how do changes in porewater carbonate chemistry correlate with changes in the overlying water column?; (ii) is there a difference in vertical porewater profiles of DIC, TA and $\mathrm{pH}$ between the different study sites, including differences between the vegetated and unvegetated sediment in Mission Bay?; and, (iii) what is the diel variability of these parameters in the different sediments? These questions were addressed by conducting a 24-h study at each site measuring an array of physical and chemical parameters with temporal resolution ranging from minutes to hours.

\section{Methods}

\subsection{Site Description}

\subsubsection{Mission Bay, San Diego}

Mission Bay $\left(32.79^{\circ}-117.23^{\circ}\right)$ is located in San Diego, California, USA (Fig. 2). It is a semi-enclosed but well-mixed, mesotidal estuary spanning $17.1 \mathrm{~km}^{2}$ with extensive anthropogenic modifications including artificial islands and beaches (Obaza et al. 2015). Due to low freshwater inputs and high evaporation rates, Mission Bay is typically slightly hypersaline $(S \approx 34-36)$ compared to open ocean water (Largier et al. 1997). However, periods of heavy rainfall and freshwater discharge significantly lower the salinity of the bay (Elliott and Kaufmann 2007). Porewater salinity in Mission Bay has been found to range between 30 and 40 with an average $( \pm$ SE) porewater salinity at the study site of $35 \pm 1$ (Talley et al. 2015). The Kendall-Frost Mission Bay Marsh Reserve is located in the northeastern part of the bay, spanning approximately $65,000 \mathrm{~m}^{2}$. The reserve is mainly comprised of a saltmarsh, mudflats, and, below the $0 \mathrm{~m}$ tide level, a vast eelgrass bed (Zostera marina) down to $\sim 2 \mathrm{~m}$ depth (Levin 1984). The benthic community in the reserve consists mainly of dense patches of eelgrass with a few occurrences of widgeongrass (Ruppia maritima) (Johnson et al. 2003) growing on muddy, siliciclastic sediment. Shoot densities of Z. marina vary seasonally from as low as $\sim 20$ shoots $\mathrm{m}^{-2}$ at temperature maxima in late summer and during storm events in the winter to $>300$ shoots $\mathrm{m}^{-2}$ in late fall and spring (Johnson et al. 2003). During the sampling period in Spring 2017, patches of dead Z. marina were observed, many of which were overgrown by ephemeral algae, as shown in the supplementary material (Online Resource 1). 


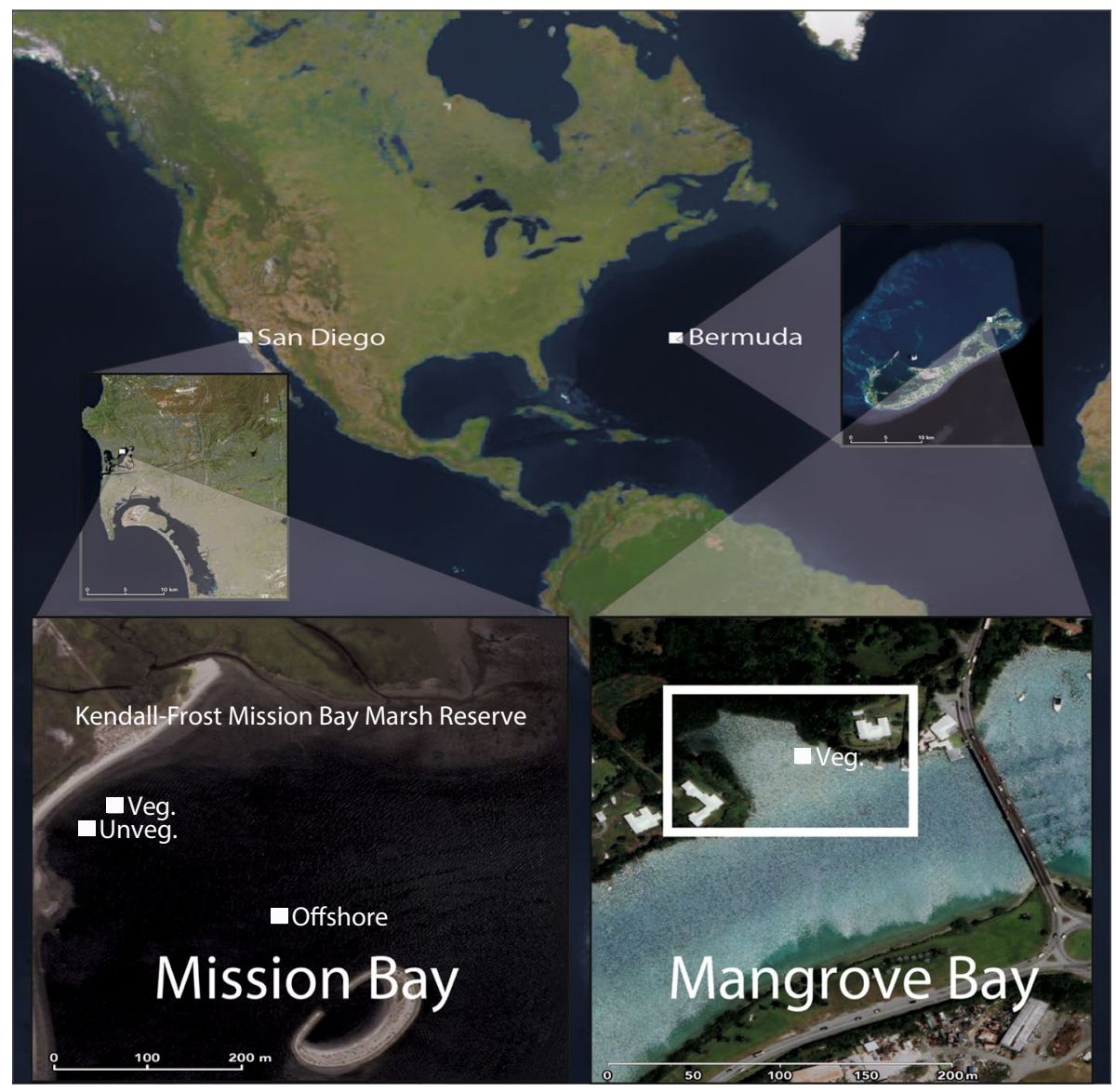

Fig. 2 Location of sampling sites in Mission Bay, San Diego, USA and Mangrove Bay, Ferry Reach, Bermuda. Shown are the sites of the porewater wells (vegetated and unvegetated) and where offshore reference samples were taken in Mission Bay. Mangrove Bay is denoted by a white rectangle

The weather was sunny and dry during the April 25-26, 2017 sampling event. However, the winter and early spring of 2017 (Jan-Apr) brought over $100 \mathrm{~mm}$ of precipitation to the area (https://www.weather.gov/climate/index.php?wfo=sgx).

\subsubsection{Mangrove Bay, Ferry Reach, Bermuda}

Mangrove Bay $\left(32.37^{\circ}-64.69^{\circ}\right)$ is located on St. George's Island in the eastern part of Bermuda and is considerably smaller than Mission Bay, spanning approximately $3350 \mathrm{~m}^{2}$ (Fig. 2). Freshwater input is supplied from rain- and groundwater (approximately $4 \%$ by volume), as no rivers or streams connect to the bay, and salinity has been found to range from 33.2 to 37.2 over a diel cycle (Zablocki et al. 2011). The benthic flora consists mainly of seagrass Thallasia testudinium and green algae surrounded by large stands of black and red mangrove trees (Zablocki et al. 2011). T. testudinium is prevalent but sparsely distributed across the bay with increased patchiness closer to shore. Shoot density has been found to range between 80 and 370 shoots $\mathrm{m}^{-2}$ (unpublished data). 
Sediments are comprised of carbonate mud with varying amounts of larger $\mathrm{CaCO}_{3}$ grain sizes, mainly derived from calcareous algae and limestone (Lyons et al. 1980; Hines and Lyons 1982). Although at a similar latitude as San Diego, Bermuda's location in the North Atlantic Subtropical Gyre makes the climate subtropical with surface water temperatures ranging from 16 to $30{ }^{\circ} \mathrm{C}$ between winter and summer.

\subsection{Sample Collection}

\subsubsection{Mission Bay, San Diego}

A 24-h study was conducted in Kendall-Frost Mission Bay Marsh Reserve in Mission Bay, San Diego on April 25-26, 2017. During the entire study period (March-May), two temperature sensors (HOBO logger, Onset) recording temperature every $5 \mathrm{~min}$ were submerged in the sediment at 8 and $16 \mathrm{~cm}$ depth. Prior to the sampling study in April, two additional HOBO loggers measuring temperature and irradiance every 5 min were deployed on the bottom in the vegetated and unvegetated site. Illuminance data (in lux) were converted to photosynthetically active radiation (PAR) according to Long et al. (2012). Data of air temperature and precipitation were obtained from NOAA's National Climatic Data Center (NCDC, Menne et al. 2012).

Water column samples directly above the sediment-water interface (SWI) were collected immediately before and after each porewater well (PWW) sampling, using $250 \mathrm{~mL}$ Pyrex narrow-neck borosilicate glass bottles. Surface water samples $\sim 500 \mathrm{~m}$ offshore from the PWW sites (Fig. 2) were collected immediately before PWW sampling to serve as a reference location. All water column samples were poisoned with $100 \mu \mathrm{L}$ saturated solution of $\mathrm{HgCl}_{2}$ and sealed according to standard protocol (Dickson et al. 2007). In conjunction with water column sampling, in situ temperature $\left( \pm 0.3{ }^{\circ} \mathrm{C}\right)$, salinity $( \pm 1.0 \%)$ and dissolved oxygen (DO) $( \pm 2 \%)$ were measured with a YSI Pro2030 multiprobe (Xylem). Salinity was calibrated to seawater Certified Reference Material (CRM, Dr. A. Dickson, SIO) prior to sampling, and oxygen was calibrated in air at $100 \%$ humidity assuming $100 \%$ oxygen saturation.

Samples of sediment porewater were collected by submerging PWWs with intake at different depths in the sediment. All PWWs were constructed in the laboratory based on a modified design from Falter and Sansone (2000). PWWs were deployed in a dense patch of $Z$. marina covering depths of 2, 4, 6, 8, 12, and $16 \mathrm{~cm}$ below the SWI. PWWs were also deployed in an adjacent unvegetated area ( $\sim 2$ meters away) at the same depth and served as a control site. At each location, wells were deployed approximately $30 \mathrm{~cm}$ apart from each other to reduce the risk of overlapping with porewater extracted from adjacent wells (Falter and Sansone 2000; Drupp et al. 2016). All PWWs $(n=12)$ were deployed four days prior to the sampling event. Porewater samples were collected four times during the 24-h study at morning high tide (HT), afternoon low tide (LT), evening HT and morning LT via freediving from a kayak (Table 1). Samples were collected using a 30-mL syringe that attached to the PWW 3-way stopcock valve through a luer lock connection. Depending on the depth of the PWW, a "dead" volume representing that of the entire tubing and well cylinder was first drawn and discarded in order to clear out water sitting in the well. Syringes with sample were taken back to shore and filtered through $0.45 \mu \mathrm{m}$ Minisart ${ }^{\circledR}$ polyethersulfone sterile filters (Sartorius) and placed in 25 -mL glass vials. Filtering samples introduce a risk of $\mathrm{CO}_{2}$ gas exchange which could influence DIC measurements. However, this procedure is necessary as extraction of porewater inevitably carries suspended colloidal 
Table 1 Tides (relative to mean lower low water (MLLW)) in Mission Bay and relative water level height in Mangrove Bay during the sampling periods

\begin{tabular}{lllll}
\hline \multicolumn{2}{l}{ Mission Bay } & & & \multicolumn{2}{l}{ Mangrove Bay } \\
\cline { 1 - 3 } \cline { 5 - 6 } Time & Height $(\mathrm{m})$ & & Time & Height $(\mathrm{m})$ \\
\hline 4/25/2017 09:12 & 1.55 & & $9 / 18 / 200510: 12$ & 1.58 \\
$4 / 25 / 201715: 23$ & 0.03 & & $9 / 18 / 200516: 03$ & 0.54 \\
$4 / 25 / 201721: 17$ & 1.89 & & $9 / 18 / 200522: 05$ & 1.59 \\
$4 / 25 / 201704: 07$ & -0.28 & & $9 / 19 / 200503: 57$ & 0.56 \\
\hline
\end{tabular}

Mission Bay (Crown Point) tide data were obtained from the National Oceanic and Atmospheric Administration (NOAA) Tides and Currents website (https://tidesandcurrents.noaa.gov). The tide in Mangrove Bay was measured every $2 \mathrm{~h}$ using a tidal stick. Water depth at morning low tide was $\sim 30 \mathrm{~cm}$ at both sites

and clay-sized carbonate particles which would react with the acid addition in subsequent DIC and TA analyses. We employed a similar technique and same filter size as in Bockmon and Dickson (2014) in which no significant difference in DIC between filtered and unfiltered samples was observed. Samples were immediately poisoned with $25 \mu \mathrm{L} \mathrm{HgCl}_{2}$ to cease any biological activity in the sample. Vials were sealed with a rubber stopper and an aluminum crimp seal. Concurrently, $5 \mathrm{~mL}$ of non-filtered and non-poisoned sample were used to measure $\mathrm{pH}$ using an Accumet glass electrode with an Orion Star Plus handheld $\mathrm{pH}$ meter (Thermo Scientific). The glass electrode was calibrated with a two-point calibration to NIST buffers (pH 4 and 7) and to tris(hydroxymethyl)aminomethane (Tris) buffer in artificial seawater $(\mathrm{pH} \sim 8.1$ and salinity 35, prepared following recipe by DelValls and Dickson (1998)) to correct for the shift of the calibration curve due to salinity and to yield $\mathrm{pH}$ measurements on the total hydrogen ion scale $\left(\mathrm{pH}_{\mathrm{T}}\right)$.

Sediment cores were collected three weeks after the sampling event using 30-cm-long transparent polycarbonate cylinders (Thermoplastic Processes) with an inner diameter of $7.3 \mathrm{~cm}$. After the cylinder was emplaced into the sediment, a sealing lid was put on top of the cylinder to create a vacuum whereby a sediment core could be collected.

\subsubsection{Mangrove Bay, Bermuda}

A 24-h study was conducted between September 18-19, 2005 covering a full tidal cycle (Table 1). Water column $(n=13)$ and porewater $(n=78)$ samples were collected every $2 \mathrm{~h}$ between morning HT (10:12) and morning HT (10:03) the following day. However, due to issues with instrumentation, porewater samples of $\mathrm{pH}(\mathrm{n}=60)$ were only collected until morning LT (03:57). Similar to the study in Mission Bay, temperatures were recorded in conjunction with each sampling using a temperature probe. Water column samples were collected using a 5 L Niskin sampler. Samples for DIC and TA were drawn into 200-mL Kimax glass bottles, poisoned with $\mathrm{HgCl}_{2}$ and sealed for subsequent analysis at Bermuda Institute of Ocean Science (BIOS). Samples for DO were drawn into 115-mL BOD (Biological Oxygen Demand) bottles and immediately fixed with Winkler reagents. Samples for salinity were collected in salinity glass bottles. These DO and salinity samples were also analyzed at BIOS.

Porewater samples were collected in a sparse patch of T. testudinium in a similar manner to the Mission Bay study, using PWWs based on the same design and sampled at 2, 4, 6, 8, 12 and $16 \mathrm{~cm}$ below the SWI. For each porewater sample, a small volume was 
drawn from the syringe into a small vial and analyzed for $\mathrm{pH}$ immediately after sampling. The remaining sample was then filtered, poisoned and transferred into sealed $25-\mathrm{mL}$ glass vials for subsequent DIC analysis at BIOS. Surface and bottom water temperatures were recorded with a YSI in conjunction with each sampling (every $2 \mathrm{~h}$ ). Two HOBO loggers were emplaced in the sediment at 8 and $16 \mathrm{~cm}$ depth, continuously recording temperature at five-minute intervals.

\subsection{Sample Analysis}

\subsubsection{Mission Bay, San Diego}

Porewater $(n=48)$, bottom $(n=4)$ and surface $(n=4)$ water samples were analyzed for DIC, TA and pH in the Scripps Coastal and Open Ocean Biogeochemistry Laboratory at SIO. DIC was measured using an Automated Infrared Inorganic Carbon Analyzer (AIRICA, Marianda, Inc.) equipped with a LI-COR 7000 infrared $\mathrm{CO}_{2}$ analyzer (Li-COR), with the average integrated value of a triplicate measurement $(0.5 \mathrm{~mL}$ each $)$ determined relative to the integrated value of a CRM (batch 149 and 151; Dr. A. Dickson, SIO). The average offset from the certified value was $-0.3 \pm 3 \mu \mathrm{mol} \mathrm{kg}{ }^{-1} \cdot \mathrm{pH}_{\mathrm{T}}$ was determined spectrophotometrically using a Sami AFT-pH (Sunburst sensors, LLC) with meta-Cresol Purple (mCP) as indicator reagent. Accuracy and precision $(-0.019 \pm 0.008$ units) of the instrument were periodically verified using either calculated $\mathrm{pH}_{\mathrm{T}}$ of CRM (Dr. A. Dickson, SIO) or Tris buffer in artificial seawater (following recipe by DelValls and Dickson (1998)).

TA was determined using open-cell potentiometric titration with an 888 Titrando (Metrohm) titration system using an Ecotrode Plus $\mathrm{pH}$ glass electrode (Metrohm). Samples (10-15 g) were titrated with prepared $0.01 \mathrm{~mol} \mathrm{~kg}^{-1} \mathrm{HCl}$ in $0.6 \mathrm{~mol} \mathrm{~kg}^{-1} \mathrm{NaCl}$ and TA was calculated using a modified Gran function (Gran 1952). Accuracy and precision $\left(0.0 \pm 1.5 \mu \mathrm{mol} \mathrm{kg} \mathrm{kg}^{-1}\right)$ were determined using CRM. Measured values of TA were compared to calculated values (from DIC and $\mathrm{pH}_{\mathrm{T}}$ ) using the MATLAB program CO2SYS v. 1.1 (Lewis and Wallace 1998) with in situ values of temperature, salinity, DIC and $\mathrm{pH}_{\mathrm{T}}$ as inputs. Dissociation constants $\mathrm{K}_{1}^{*}$ and $\mathrm{K}_{2}^{*}$ were adopted from Mehrbach et al. 1973 as refit by Lueker et al. (2000). TA samples with a mass below $\sim 10 \mathrm{~g}(n=17)$ were diluted with de-ionized water (Milli-Q) prior to titration. A dilution factor was obtained by titrating multiple CRM samples $(n=8)$ with different volumes of dilute in order to account for the nonlinear behavior of the electrode in diluted samples. A polynomial equation was parameterized to the offset from the certified CRM value and that equation was used to correct for the TA value of diluted samples. For samples that did not have sufficient volume for titration $(n=4)$, the TA value calculated from DIC and $\mathrm{pH}_{\mathrm{T}}$ as described above was used.

\subsubsection{Mangrove Bay, Bermuda}

Seawater samples were analyzed for DIC and TA following the same procedures described for Mission Bay samples, but with slightly different instrumentation. DIC was analyzed using an infrared analyzer (LI-COR 6262 NDIR) and TA was analyzed using a Brinkmann 665 Dosimat, equipped with a Brinkmann $654 \mathrm{pH}$ meter (Metrohm) following the methods described in Dickson and Goyet (1994). Accuracy and precision for DIC and TA measurements were within $\pm 3 \mu \mathrm{mol} \mathrm{kg}{ }^{-1}$ (CRM, batch 71). Samples for DO were analyzed by Winkler titration, following the procedures used by the Bermuda Atlantic Timeseries Study (BATS) (Knap et al. 1997) and salinity was measured with an Autosal 8400A 
salinometer (Guildline Instruments). Porewater samples were analyzed for DIC as previously described, and $\mathrm{pH}$ was determined immediately after sample collection using a handheld Accumet AP72 glass electrode (Thermo Fisher Scientific), calibrated to NIST buffers. Note that calibration was only made with low ionic strength buffers, and thus, relatively high uncertainty is anticipated with respect to the absolute values of these measurements. However, comparison of calculated $\mathrm{pH}_{\mathrm{T}}$ from DIC and TA of bottom water $(n=13)$ with measured $\mathrm{pH}$ revealed an offset of $0.01 \pm 0.003 \mathrm{pH}$ units.

\subsubsection{Sediment Analyses}

Sediment cores $(n=2)$ collected at the two sites in Mission Bay were photographed immediately after collection and brought back to SIO for subsequent grain size analyses. A plunger was used to extract the core from the sampler, the core was sliced into 2-cm-thick slices, and each slice was then cut in half. A subsample representative of the entire depth of each core was sieved through 1000, 500, 250, 125 and $63 \mu \mathrm{m}$ mesh sizes. Particles smaller than $63 \mu \mathrm{m}$ were collected in a separate container of deionized water and left for one week to settle. The different grain size fractions were dried in an oven at $60{ }^{\circ} \mathrm{C}$ for one week and weighed individually in order to calculate a relative mass (\% dry weight) of bulk weight for each grain size.

In Mangrove Bay, no sediments were collected at the time of the study. However, a similar study took place in 2009 (unpublished data) when sediment samples from five different locations in the bay were collected. An average of grain size distributions from these five locations was used in the present study.

\subsection{Data Analyses and Uncertainty Assessments}

To evaluate the coupling between bottom water and porewater, the time lag between changes in temperature at different sediment depths was evaluated. The temperature lag within the sediment was defined as the time it takes for an observed temperature signal to propagate between two depths $(0-8 \mathrm{~cm}, 8-16 \mathrm{~cm}$ and $0-16 \mathrm{~cm}$, respectively) and was calculated by cross-correlation using the MATLAB function xcorr.

Grain size distributions were assessed using the Excel package GRADISTAT v.4.0 (Blott and Pye 2001). Differences in grain size distribution between the sites were assessed using a two-sample Kolmogorov-Smirnov test.

To assess relationships between TA and DIC, type II linear regressions were performed using the MATLAB script lsqfitma.m (http://www.mbari.org/staff/etp3/regress.htm), plotted on $\mathrm{pH}_{\mathrm{T}}$ isopleths calculated with CO2SYS. Confidence intervals (CI 95\%) of the slopes were used to assess difference in slopes between sites. Furthermore, to assess differences in average porewater concentrations of DIC and TA, the depth-integrated concentration was calculated as the sum of the concentrations at each depth multiplied by the respective depth interval $(2$ or $4 \mathrm{~cm})$ and divided by the total sample depth $(16 \mathrm{~cm})$. The mean depth-integrated concentration of each sampling was calculated to obtain a diel average.

In order to calculate all parameters of the aqueous $\mathrm{CO}_{2}$ system, two of the four master variables DIC, TA, $\mathrm{pH}$ or $\mathrm{pCO}_{2}$ (partial pressure of $\mathrm{CO}_{2}$ ) are needed in conjunction with temperature, salinity and pressure (Zeebe and Wolf-Gladrow 2001). In the Mission Bay study however, three master variables (DIC, TA and $\mathrm{pH}$ ) were measured and $\mathrm{pH}$ was measured twice for each sample-both in conjunction with sampling using a glass electrode and subsequently in the laboratory by spectrophotometry. Over-determining the 


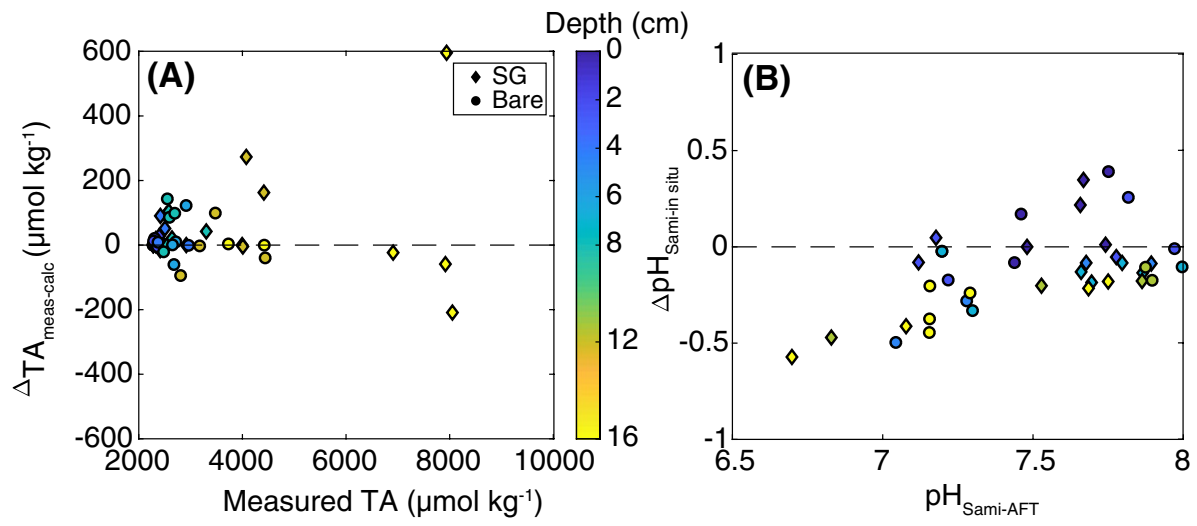

Fig. 3 a The difference between measured and calculated TA plotted against the measured TA $(n=51)$. b The difference between $\mathrm{pH}_{\mathrm{T}}$ measured in situ and $\mathrm{pH}_{\mathrm{T}}$ measured with Sami AFT-pH $(n=38)$. Colors indicate the sediment depth from which samples were collected

$\mathrm{CO}_{2}$ system allows for additional quality control and assessment of potential errors and uncertainty. For example, measured $\left(\mathrm{TA}_{\text {meas }}\right)$ and calculated $\left(\mathrm{TA}_{\text {calc }}\right)$ values of TA (from DIC and $\mathrm{pH}_{\mathrm{T}}$ ) exhibited better agreement at shallower sediment depth, but the variability increased with sediment depth (Fig. 3a). In nearly all samples from $\geq 8 \mathrm{~cm}$ depth, $\mathrm{HgS}$ precipitated when $\mathrm{HgCl}_{2}$ was added. This reaction reduces alkalinity and increases the uncertainty of the measurements (Goyet et al. 1991). Regrettably, precipitation of $\mathrm{HgS}$ was not quantified and its effect on TA is therefore not known, which constitutes a risk of underestimating TA and TA:DIC ratios at sediment depths $\geq 8 \mathrm{~cm}$. TA meas $_{\text {values were }}$ used in the results except where the sample volume was insufficient for titration and $\mathrm{TA}_{\text {calc }}$ was used instead $(n=4)$.

When comparing $\mathrm{pH}_{\mathrm{T}}$ values measured with glass electrode in situ to those measured spectrophotometrically in the laboratory, a pattern similar to that seen between calculated and measured TA was observed. In general, the $\mathrm{pH}_{\mathrm{T}}$ values agreed well at shallower depths but the discrepancy increased with lower $\mathrm{pH}_{\mathrm{T}}$ values (i.e., deeper depths) (Fig. 3b). Oxygen contamination and subsequent sulfide oxidation, $\mathrm{HgS}$ precipitation or a combination of the two could partly explain this discrepancy.

The seawater saturation state of $\mathrm{CaCO}_{3}$ with respect to aragonite $\left(\Omega_{\mathrm{Ar}}\right)$ was calculated using DIC and TA as master variables, with in situ temperature, salinity and pressure. Dissociation constants $\mathrm{K}_{1}^{*}$ and $\mathrm{K}_{2}^{*}$ were adopted from Mehrbach et al. 1973 as refit by Lueker et al. (2000).

\section{Results}

\subsection{Water Column Variability of Environmental and Chemical Parameters}

\subsubsection{Mission Bay, San Diego}

The tidal range in Mission Bay was $2.17 \mathrm{~m}$ with low tides at 15:23 and 04:07 and high tides at 9:12 and 21:17 during the study (Table 1). Water column temperature increased 
during outgoing tides and decreased with incoming tides regardless of the time of day (Fig. 4). Hence, the warmest temperatures coincided with low tides and coldest temperatures with high tides. Longer-term recordings (April-May) of water column temperature in Mission Bay showed similar variability, largely controlled by the semi-diurnal tidal cycle (Online Resource 2). Salinity did not reveal any temporal trend (Fig. 4).

DIC and TA exhibited temporal variability that revealed combined influences from the light and tidal cycle with lower concentrations in the afternoon and evening, and higher in the mornings (Fig. 4). The highest DIC and TA values were observed at morning low tide and the lowest at evening high tide. $\mathrm{pH}_{\mathrm{T}}$ and $\Omega_{\mathrm{Ar}}$ exhibited the opposite trend with minimum values observed at morning low tide and maximum values observed at evening high tide (Fig. 4). Notably, the low DIC and TA and high $\mathrm{pH}_{\mathrm{T}}$ and $\Omega_{\mathrm{Ar}}$ values were observed in the evening after sunset and coincided with a relatively elevated, high tide. DO also showed a similar trend with lowest values in the morning and highest values during the evening high tide (Fig. 4).
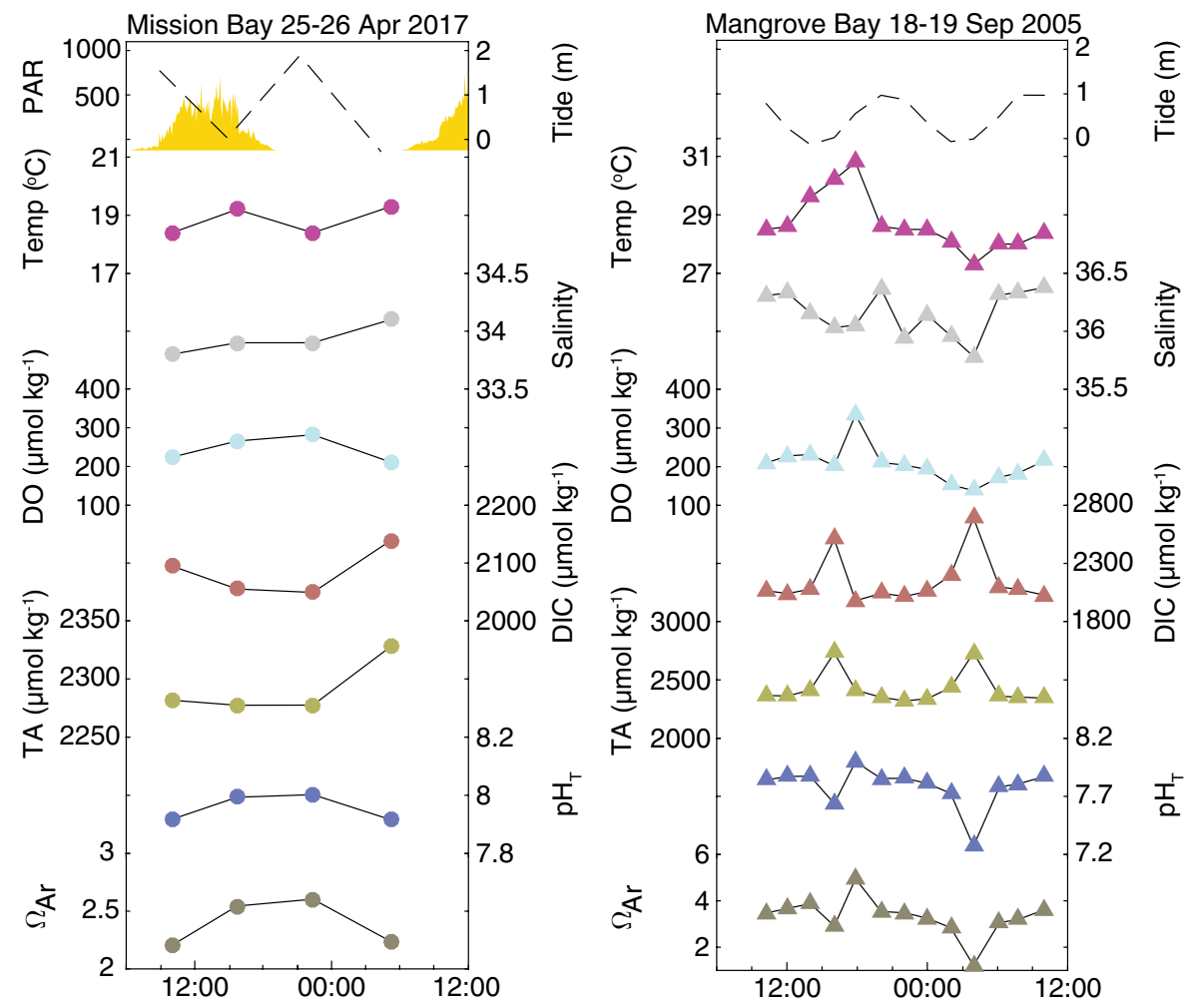

Fig. 4 Water column time series in Mission Bay (a) and Mangrove Bay (b) of tide, temperature, salinity, DO, DIC, TA, $\mathrm{pH}_{\mathrm{T}}$ and $\Omega_{\mathrm{Ar}}$. In (a), photosynthetically active radiation (PAR) is also plotted, given in $\mu \mathrm{mol} \mathrm{m} \mathrm{m}^{-2} \mathrm{~s}^{-1}$ 


\subsubsection{Mangrove Bay, Bermuda}

Low and high tides in the Mangrove Bay study occurred at similar times as in the Mission Bay study (Fig. 4), but the $1 \mathrm{~m}$ tidal range was approximately half the range of Mission Bay tides (Table 1). Water column temperature reached a maximum of $30.8{ }^{\circ} \mathrm{C}$ in the late afternoon and a minimum of $27.3^{\circ} \mathrm{C}$ at night coincident with low tide. Similar to Mission Bay, there was no clear trend in salinity albeit the lowest salinity value occurred at low tide at night (Fig. 4). Seawater carbonate chemistry properties strongly followed the tidal signal with maximum DIC and TA and minimum $\mathrm{pH}_{\mathrm{T}}$ and $\Omega_{\mathrm{Ar}}$ observed coincident with low tides regardless of the time of the day (Fig. 4). For all water column biogeochemical parameters, the largest change measured between two consecutive samplings occurred between slack water at low tide and the following sampling during flood tide. Between low tides, carbonate chemistry properties were relatively invariable. For most of the times, DO appeared to mirror DIC and tracked the trends in $\mathrm{pH}_{\mathrm{T}}$ and $\Omega_{\mathrm{Ar}}$ (Fig. 4).

\subsection{Connectivity Between Water Column and Porewater Properties}

Based on temperature measurements in the water column and within the sediments in both Mission Bay and Mangrove Bay, it appears that changes in the water column were translated into the sediment porewaters albeit with a time lag and dampened variability as one moves into the sediments (Fig. 5). That is, a decrease or increase in temperature in the water column was followed by a decrease or increase in porewater temperatures. Both the time lag and the dampening of variability increased with increasing sediment depth. In Mission Bay, the time lag was $2.4 \mathrm{~h}$ between 0 and $8 \mathrm{~cm}, 2.6 \mathrm{~h}$ between 8 and
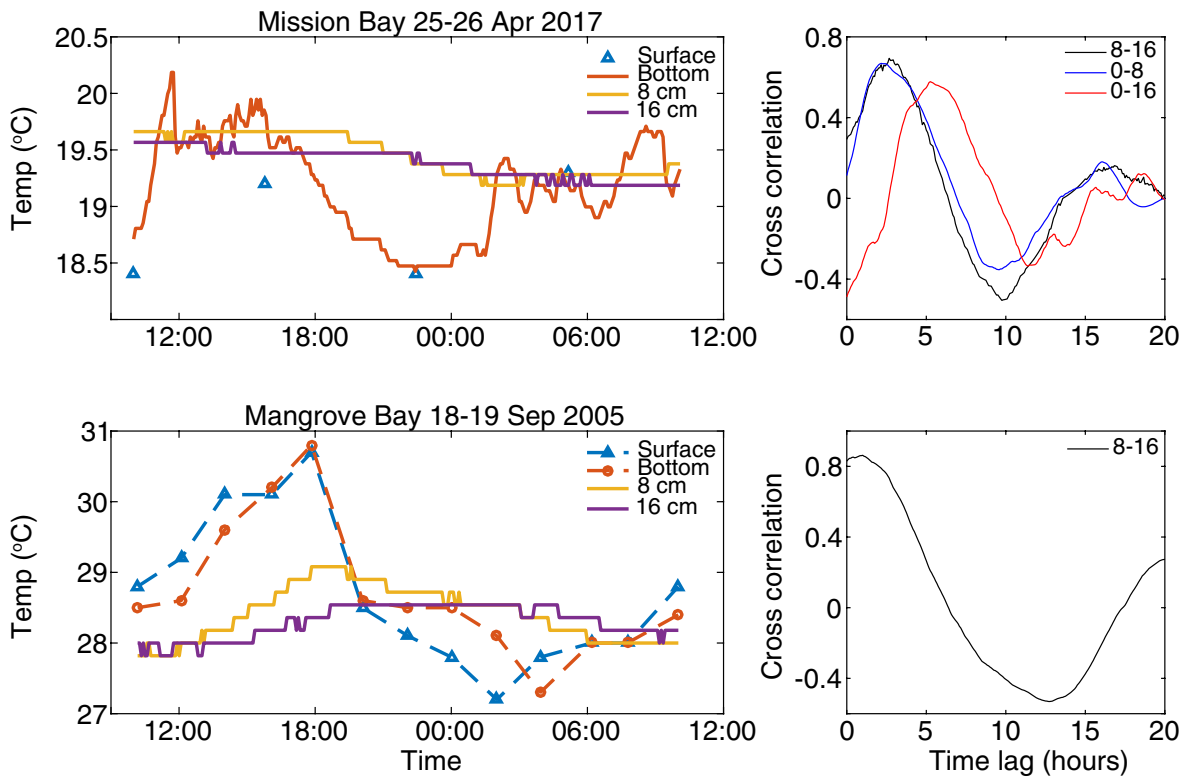

Fig. 5 Water column and porewater temperatures at 8 and $16 \mathrm{~cm}$ in Mission Bay (a) and Mangrove Bay (b). c and $\mathbf{d}$ show the time lag in temperature between the different depths. This was obtained by cross-correlation where the dominating lag time is illustrated by the first peak of respective depth interval 
$16 \mathrm{~cm}$ and $5 \mathrm{~h}$ between 0 and $16 \mathrm{~cm}$ (Fig. 5). Similar lags and dampening of variability were observed in Mangrove Bay, but the observed time lag between porewater temperatures at 8 and $16 \mathrm{~cm}$ was $<1 \mathrm{~h}$. Longer-term monitoring (April-May) of temperature in the bottom waters and in sediments of Mission Bay reaffirmed that the observed correlation and lag between bottom water and porewater were temporally consistent properties at this site (Online Resource 2). No such long-term observations were available for Mangrove Bay.

\subsection{Porewater Carbonate Chemistry Properties and Variability}

Overall, the mean and the temporal variability in porewater carbonate chemistry parameters differed between the different locations and exhibited marked vertical zonation through the sediment. In general, DIC and TA increased and $\mathrm{pH}_{\mathrm{T}}$ and $\Omega_{\mathrm{Ar}}$ decreased with sediment depth $(0-16 \mathrm{~cm})$. Over the 24-h studies, Mission Bay and Mangrove Bay differed in that a semi-diurnal signal in porewater chemistry was observed at some depths in Mangrove Bay whereas no pronounced temporal trend was observed in Mission Bay (Figs. 6, 7).
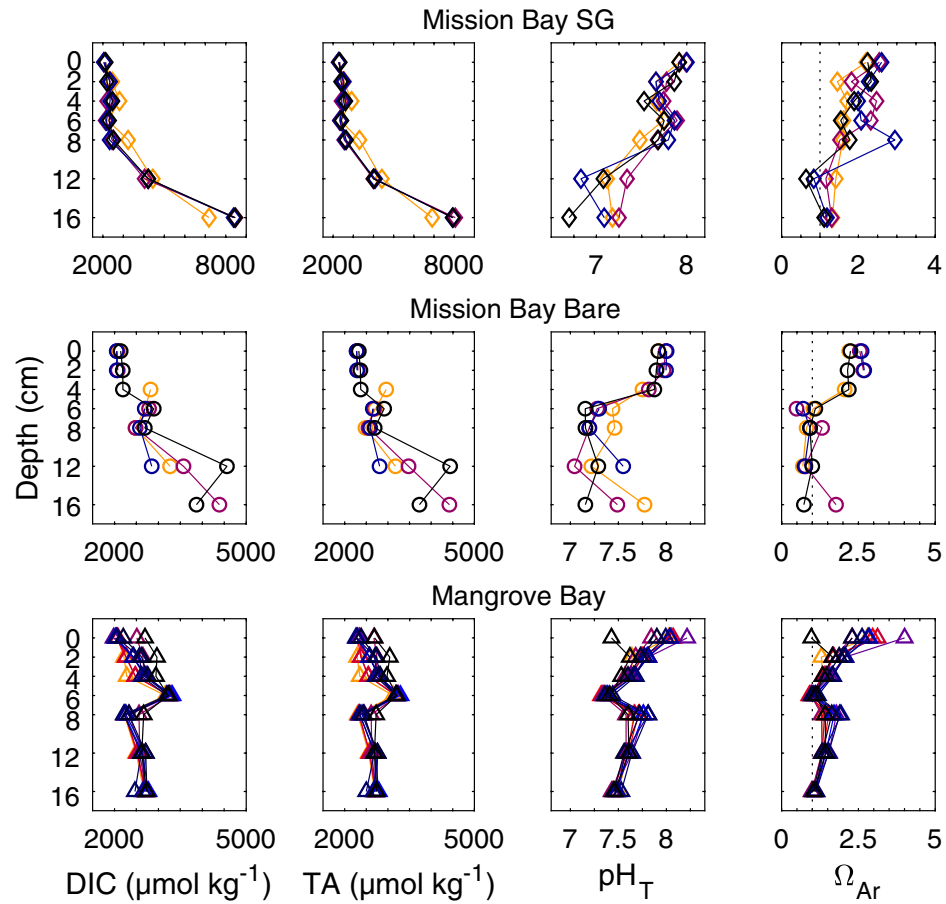

DIC $\left(\mu \mathrm{mol} \mathrm{kg}{ }^{-1}\right) \quad$ TA $\left(\mu \mathrm{mol} \mathrm{kg}{ }^{-1}\right)$

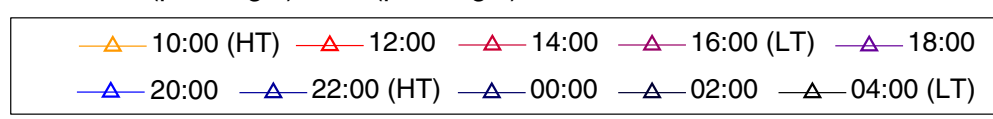

Fig. 6 Vertical porewater profiles of DIC, TA, $\mathrm{pH}_{\mathrm{T}}$, and $\Omega_{\mathrm{Ar}}$ for Mission Bay Seagrass ( $n=28$ ) (top panel), Mission Bay Bare $(n=23)$ (mid panel) and Mangrove Bay Seagrass $(n=70)$ (bottom panel). Dashed line in $\Omega_{\text {Ar }}$ plots indicate $\Omega_{\text {Ar }}=1$. Note that X-axis limits differ between sites 

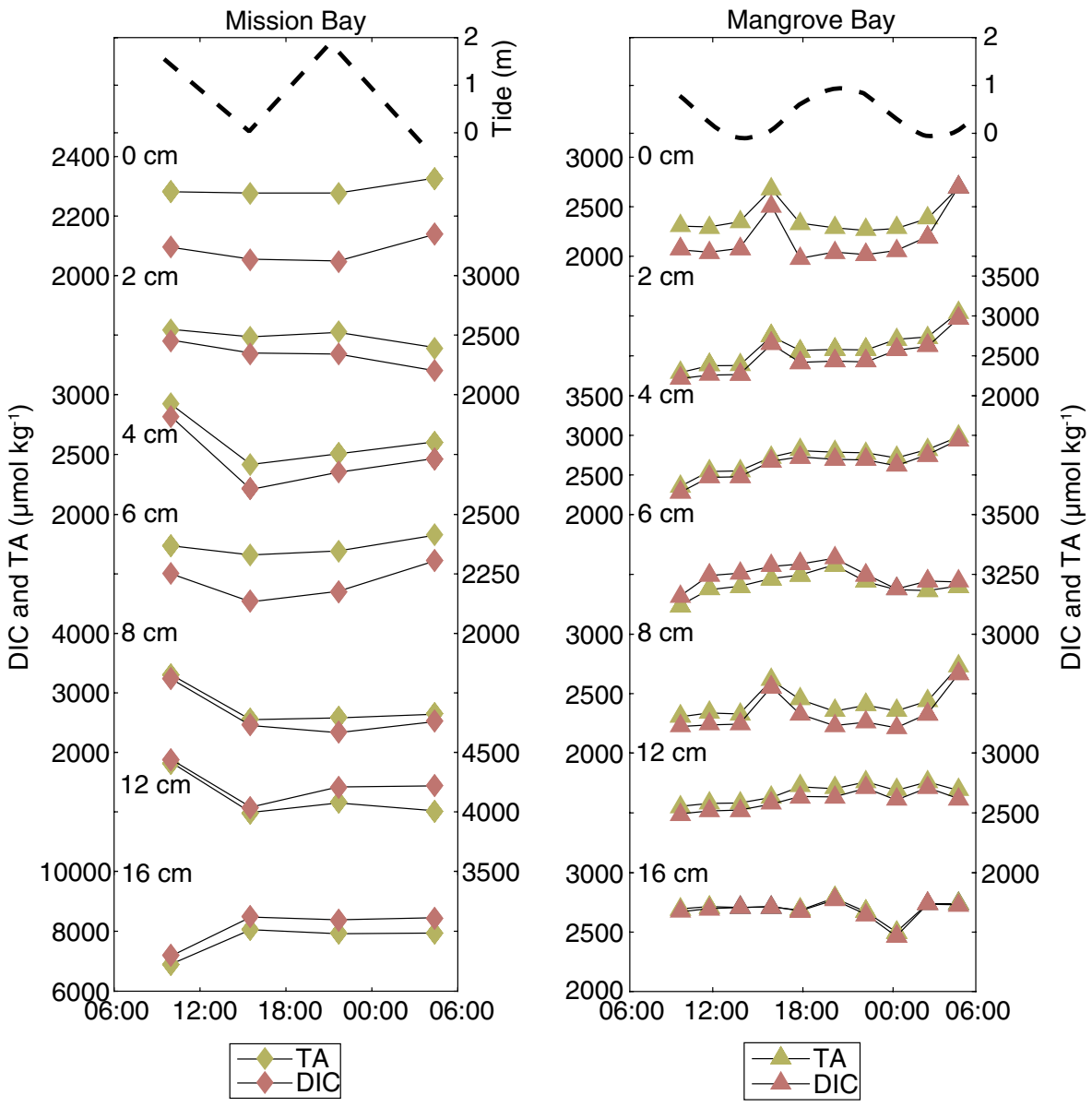

Fig. 7 Time series of porewater DIC and TA at different sediment depths for Mission Bay (left) and Mangrove Bay (right). Only the seagrass site in Mission Bay is shown

\subsubsection{Vertical Distribution and Variability}

3.3.1.1 Mission Bay, San Diego The vertical porewater profiles of carbonate parameters exhibited strong gradients at both the vegetated and unvegetated sites with increasing concentrations of DIC and TA with sediment depth. These parameters were relatively constant from the SWI down to $8 \mathrm{~cm}$ where a large increase down to $16 \mathrm{~cm}$ was observed. At the seagrass site, the diel depth-integrated $(0-16 \mathrm{~cm})$ DIC and TA were on average $4293 \pm 45$ and $4489 \pm 506 \mu \mathrm{mol} \mathrm{kg}{ }^{-1}$, respectively. The vertical variability was largest at the Mission Bay seagrass site with average DIC and TA values increasing more than threefold between 8 and $16 \mathrm{~cm}$ (Fig. 6). Similar patterns were observed for $\mathrm{pH}_{\mathrm{T}}$ and $\Omega_{\mathrm{Ar}}$, and the porewater at $12 \mathrm{~cm}$ was undersaturated with respect to aragonite during evening HT and morning LT (Fig. 6).

At the unvegetated Mission Bay site, porewater profiles of carbonate parameters were different compared to the seagrass site, albeit with maxima and minima at the same depths. Average DIC and TA values were generally lower than in the seagrass sediment, with a depth-integrated diel average of $3066 \pm 304$ and $3060 \pm 298 \mu \mathrm{mol} \mathrm{kg}^{-1}$, respectively. The 
largest difference was observed at $16 \mathrm{~cm}$ where the concentrations of DIC and TA were about half as high as in the seagrass sediment. A similar trend was observed in $\mathrm{pH}_{\mathrm{T}}$ where a distinct drop of $\sim 0.5 \mathrm{pH}_{\mathrm{T}}$ units was seen between 4 and $6 \mathrm{~cm}$ depth. Porewaters in the unvegetated site were consistently undersaturated with respect to aragonite at $12 \mathrm{~cm}$ depth and, during all but the afternoon sampling, at $8 \mathrm{~cm}$ depth (Fig. 6).

3.3.1.2 Mangrove Bay, Bermuda Porewater vertical profiles of carbonate parameters showed markedly different patterns in Mangrove Bay compared to Mission Bay. Overall, the range between minimum and maximum concentrations of porewater carbonate parameters across depth was considerably lower than that observed in Mission Bay and the profiles exhibited a much different shape (Fig. 6). Here, values of DIC and TA increased with depth down to a distinct inflection point at $6 \mathrm{~cm}$ depth. Beyond this depth, DIC and TA decreased down to $8 \mathrm{~cm}$ depth and then gradually increased with depth to $16 \mathrm{~cm}$ depth. Average depth-integrated DIC and TA over the study period was $2657 \pm 86$ and $2708 \pm 83 \mu \mathrm{mol} \mathrm{kg}^{-1}$, respectively. The vertical profiles of $\mathrm{pH}_{\mathrm{T}}$ and $\Omega_{\mathrm{Ar}}$ exhibited a similar inflection point with lowest values observed at $6 \mathrm{~cm}$. At this depth, porewaters were undersaturated with respect to aragonite $60 \%$ of the time (Fig. 6).

\subsubsection{Temporal Variability}

3.3.2.1 Mission Bay, San Diego No apparent temporal trends in porewater carbonate parameters were observed at either site in Mission Bay. At the seagrass site, concentrations of DIC and TA co-varied and exhibited the largest temporal variability in absolute concentrations at 8 and $16 \mathrm{~cm}$ whereas the largest relative change between two consecutive samplings occurred at 4 and $8 \mathrm{~cm}$ between morning HT and afternoon LT (Fig. 7). The temporal variability of $\mathrm{pH}_{\mathrm{T}}$ varied greatly between depths ranging from 7.25 to 6.70 at $16 \mathrm{~cm}$ and from 7.89 to 7.75 at $6 \mathrm{~cm}$, between afternoon LT and morning LT (Fig. 6).

At the unvegetated site, fewer samples were collected $(n=19)$ due to some of the PWWs periodically clogging which made it difficult to interpret temporal variability for porewater at 4 and $16 \mathrm{~cm}$. However, at most depths the highest values of DIC and TA were measured at morning LT concurrent with the lowest values of $\mathrm{pH}_{\mathrm{T}}$ (Fig. 6).

3.3.2.2 Mangrove Bay, Bermuda Similar to Mission Bay, DIC and TA were strongly coupled. The tidal signal observed in the water column was also seen at 2 and $8 \mathrm{~cm}$ depth in the sediment (Fig. 7). At $6 \mathrm{~cm}$, not only were DIC and TA highest and $\mathrm{pH}_{\mathrm{T}}$ and $\Omega_{\mathrm{Ar}}$ lowest, but the values stayed relatively constant throughout the study. At this depth, variability $( \pm 1 \sigma)$ of DIC and TA between all 10 samplings was only 48 and $45 \mu \mathrm{mol} \mathrm{kg}{ }^{-1}$, respectively, as compared to bottom water where these parameters on average varied $( \pm 1 \sigma)$ by 212 and $140 \mu \mathrm{mol} \mathrm{kg}{ }^{-1}$ (Table 2, Fig. 6).

\subsection{TA:DIC Relationships}

For all three sites, linear regressions of TA and DIC in the porewater were strongly correlated with $\mathrm{R}^{2}$ values close to $1\left(R^{2} \geq 0.98, p<0.001\right)$ (Fig. 8). In Mission Bay, TA:DIC slopes $( \pm 95 \% \mathrm{CI})$ of the unvegetated $(0.89 \pm 0.06)$ and vegetated $(0.90 \pm 0.01)$ sites were similar whereas the slope in Mangrove Bay was $0.85 \pm 0.03$. In the bottom water, however, the TA:DIC slopes were considerably lower compared to the slopes of the porewater in both Mission Bay $(0.56 \pm 0.13)$ and Mangrove Bay $(0.65 \pm 0.14)$ (Fig. 8). 
Table 2 Mean $( \pm 1 \sigma)$ dissolved oxygen, dissolved inorganic carbon, total alkalinity, $\mathrm{pH}$ and aragonite saturation state at the Mission Bay bottom water $(n=4)$, surface water at the offshore reference site $(n=4)$ and in the Mangrove Bay bottom water $(n=13)$

\begin{tabular}{lccc}
\hline Parameter & Mission Bay & Mission Bay (offshore) & Mangrove Bay \\
\hline $\left.\mathrm{DO}(\mu \mathrm{mol} \mathrm{kg})^{-1}\right)$ & $246 \pm 33$ & $242 \pm 23$ & $206 \pm 47$ \\
$\mathrm{DIC}\left(\mu \mathrm{mol} \mathrm{kg}^{-1}\right)$ & $2084 \pm 42$ & $2099 \pm 40$ & $2144 \pm 212$ \\
$\left.\mathrm{TA}(\mu \mathrm{mol} \mathrm{kg})^{-1}\right)$ & $2291 \pm 25$ & $2296 \pm 25$ & $2425 \pm 140$ \\
$\mathrm{pH}$ & $7.96 \pm 0.05$ & $7.94 \pm 0.04$ & $7.78 \pm 0.18$ \\
$\Omega_{\mathrm{Ar}}$ & $2.40 \pm 0.21$ & $2.32 \pm 0.16$ & $3.31 \pm 0.83$ \\
\hline
\end{tabular}

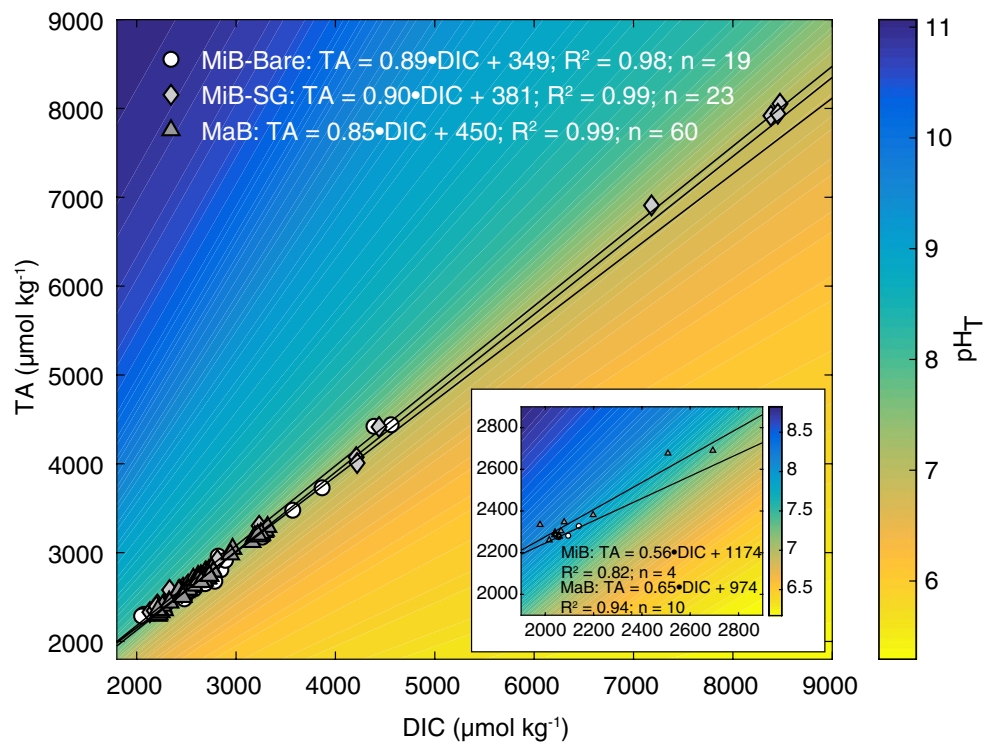

Fig. 8 Property-property plot with model II linear regression showing correlation $(p<0.001)$ between porewater TA and DIC in Mission Bay Bare (circles), Mission Bay seagrass (diamonds) and Mangrove Bay (triangles). Color isopleths show calculated $\mathrm{pH}_{\mathrm{T}}$. Enfolded plot shows TA:DIC of bottom waters $(0 \mathrm{~cm})$ in Mission Bay (filled circles) and Mangrove Bay (filled triangles)

\subsection{Sediment Grain Size Distribution}

In Mission Bay, grain size distributions were similar between the vegetated (median $\phi=3.56)$ and unvegetated site (median $\phi=3.48)$. The major grain size fractions for both sites were 125-250 $\mu \mathrm{m}$ (Bare: 31\%; SG: 31\%), <63 $\mu \mathrm{m}$ (Bare: 28\%; SG: 26\%) and 63-125 $\mu \mathrm{m}$ (Bare: 27\%; SG: 29\%) (Fig. 9). Sediments in Mangrove Bay (median $\phi=1.76)$ had larger fractions of $500-1000 \mu \mathrm{m}$ and $1000-2000 \mu \mathrm{m}($ mean $\pm 1 \sigma)$ of $23 \pm 9 \%$ and $16 \pm 9 \%$, respectively (Fig. 9). 
Fig. 9 Grain size distribution in Mission Bay (average of seagrass and bare sites) and Mangrove Bay (average of 5 locations around the PWW site)

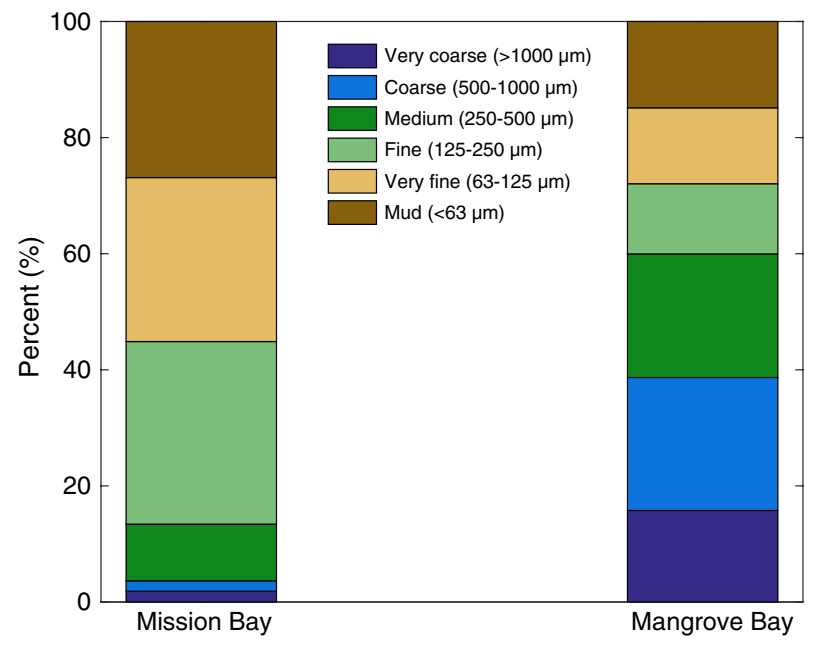

\section{Discussion}

In terms of the main objectives of this study, the results demonstrated that: (i) there was variable connectivity between the water column and the porewater at the different study sites, characterized by different temperature time lags and co-correlation of carbonate chemistry parameters in the porewater and the overlying water column, (ii) there were distinct differences in porewater carbonate chemistry between sites as a function of vegetation, sediment depth and time, and (iii) the diel variability was influenced by a combination of tidal and diurnal light cycles with the Bermuda system being strongly influenced by the semi-diurnal tidal cycles whereas only weak influences were distinguishable for the Mission Bay system. The possible properties responsible for the observed trends and variability are discussed in the subsequent sections.

\subsection{Water Column Variability}

Although variations in water column temperature over the 24-h study in Mission Bay revealed a distinct tidal signal, it is difficult to infer any clear trend from the other measured parameters due to the coarse temporal sampling resolution (Fig. 4). Yet, the highest values of DIC and TA, and the lowest values of $\mathrm{pH}_{\mathrm{T}}, \Omega_{\mathrm{Ar}}$ and DO, were observed at the two morning samplings and the observed variability over $24 \mathrm{~h}$ was likely due to a mixed effect of light intensity and tides (Fig. 4). During the mornings, the water column had experienced a full night of respiration (producing $\mathrm{CO}_{2}$ and consuming $\mathrm{O}_{2}$ ) whereas the afternoon sampling revealed a signal of net primary production (consuming $\mathrm{CO}_{2}$ and producing $\mathrm{O}_{2}$ ) (Cyronak et al. 2018a). Similar lowered DIC and elevated $\mathrm{pH}_{\mathrm{T}}$ was observed during the evening sampling, which, coincident with high tide, revealed the influence of open ocean conditions. Further, long-term measurements of temperature showed that variability was influenced both by irradiance and tides, where the temperature increased at low tide and was especially pronounced when it coincided with high irradiance (Online resource 2).

In Mangrove Bay, on the other hand, the influence of the tidal signal was observed in all water column parameters and was much more prevalent than the relatively weak diurnal 
signal, which is in agreement with observations by Zablocki et al. (2011) from the same site. The amplitude of DIC and TA between low and high tide was up to 6 times higher compared to Mission Bay (Fig. 4). This is likely due to geomorphological and physical differences between Mangrove and Mission Bay. Mangrove Bay is located in a restricted channel and is much smaller and shallower than Mission Bay, which results in greater tidal flow rates and variability in biogeochemical parameters. Mangrove Bay is also influenced by submarine groundwater discharge (SGD) (Zablocki et al. 2011) and at the same time more directly connected to the open ocean than Mission Bay, leading to large gradients between these end-members. This was evident from the changes in water column parameters during incoming and outgoing tides, where the largest change in between two consecutive samplings occurred between afternoon slack low tide and the following sampling during flood tide. Based on our observations, SGD and tidal pumping owing to rapid tidal flow (Santos et al. 2012) were probably more important factors in Mangrove Bay (Zablocki et al. 2011) than in Mission Bay.

\subsection{Spatiotemporal Variability in Porewater Carbonate Parameters}

Porewater profiles of carbonate parameters exhibited strong concentration gradients at all sites but differed substantially in both vertical and temporal variability. In Mission Bay, there was a marked difference in the vertical porewater profiles of biogeochemical parameters between the vegetated and unvegetated sites, both in terms of absolute concentrations and vertical variability (Fig. 6). At both sites, DIC and TA increased with sediment depth, but reached almost twice as high concentrations at the deepest depths $(12$ and $16 \mathrm{~cm})$ in the vegetated compared to the unvegetated sediments (Fig. 6). Over the course of the diel sampling period, this largely contributed to a depth-integrated average of DIC and TA that was $40-50 \%$ higher in the vegetated sediments than in the unvegetated. We hypothesize that this difference is due to increased seagrass detritus and labile OM from seagrass root exudates (Blaabjerg et al. 1998; Miyajima et al. 1998; Jones et al. 2003) which fuels microbial remineralization. These DIC and TA profiles observed here resembles those found in seagrass sediments reported by Burdige and Zimmerman (2002) from the Bahamas, where the combined effect of OM supply and oxygen loss from seagrass roots and rhizomes was proposed to induce coupled aerobic remineralization and $\mathrm{CaCO}_{3}$ dissolution. It is possible that these processes contributed to the difference between vegetated and unvegetated porewater DIC and TA that we observed in Mission Bay.

A general pattern of stable $\mathrm{pH}_{\mathrm{T}}$ and $\Omega_{\mathrm{Ar}}$ at shallow depths followed by a drastic decrease was observed in both vegetated and unvegetated sediments in Mission Bay. However, aragonite undersaturation (i.e., $\Omega_{\mathrm{Ar}}<1$ ) was shallower in the unvegetated sediments and was common from $6 \mathrm{~cm}$ and below. Conversely, aragonite undersaturation was observed at $12 \mathrm{~cm}$ in the vegetated sediments, but further work is necessary to assess the underlying mechanisms for this difference between vegetated and unvegetated sediments.

The porewater profiles in Mangrove Bay contrasted to those observed in Mission Bay, both in terms of vertical patterns and temporal variability (Figs. 6, 7). The maximum DIC and TA concentrations were never as high as those in Mission Bay, and depth-integrated average concentrations were about $60 \%$ lower than at the Mission Bay seagrass site. At $6 \mathrm{~cm}$ depth, DIC and TA reached their maxima with the resulting $\mathrm{pH}$ minimum and occasional undersaturation of $\Omega_{\mathrm{Ar}}$, but below this depth both $\mathrm{pH}_{\mathrm{T}}$ and $\Omega_{\mathrm{Ar}}$ were generally higher than in Mission Bay (Fig. 6). A similar pattern was observed by Drupp et al. (2016) in bare-substrate $\mathrm{CaCO}_{3}$ sediment porewater profiles from Hawaii, where a sharp drop in $\mathrm{pH}$ 
of up to 0.6 units was observed between the SWI and $6 \mathrm{~cm}$, followed by an increase below $8 \mathrm{~cm}$. These vertical trends reflect how different redox processes and subsequent mineral reactions prevail at different depths with aerobic respiration and $\mathrm{CaCO}_{3}$ dissolution predominant in oxic surface layers (sediment depth $<6 \mathrm{~cm}$ in Mangrove Bay and $\leq 8 \mathrm{~cm}$ in Mission Bay), and sulfate reduction coupled with either $\mathrm{CaCO}_{3}$ dissolution or precipitation (depending on the extent of the sulfate reduction reaction) predominant under anoxic conditions at sediment depths $>6 \mathrm{~cm}$ in Mangrove Bay and $>8 \mathrm{~cm}$ in Mission Bay (e.g., Morse and Mackenzie 1990; Ku et al. 1999; Jahnke and Jahnke 2004; Burdige et al. 2008; Mackenzie and Andersson 2011; Rao et al. 2014; Drupp et al. 2016).

In general, a gradual decrease in the influence of advective transport is expected as a function of sediment depth (Shum 1992; Santos et al. 2012; Drupp et al. 2016), yielding a lower spatial and temporal variability at greater depths. The temporal variability of carbonate parameters in Mangrove Bay largely followed this pattern, with a deviation at $8 \mathrm{~cm}$ depth, where variability was higher than at neighboring sediment depths. Notably, at $6 \mathrm{~cm}$ depth the variability was lowest and exhibited the highest porewater DIC and TA concentrations (Figs. 6, 7).

In addition to a well-defined tidal signal in the Mangrove Bay porewater, the average time lag of temperature changes between 8 and $16 \mathrm{~cm}$ was just under an hour while it was almost three hours in Mission Bay. This is likely due to a combination of increased flushing of seawater and higher sediment permeability in Mangrove Bay relative to Mission Bay. For example, the coarser median grain size and higher fraction of coarse and very coarse sand in Mangrove Bay (Fig. 9) suggest higher sediment permeability in Mangrove Bay than in Mission Bay (but see Bennett et al. 1990). Further, the three times faster temperature changes between 8 and $16 \mathrm{~cm}$ (Fig. 5) implies that the Mangrove Bay sediments have higher hydraulic conductivity than in Mission Bay. This difference in porewater residence times between Mission Bay and Mangrove Bay could explain a significant part of the observed difference in DIC and TA, with much higher concentrations at depth in the former site due to diffusion limited transport.

\subsection{Methodological Considerations and Future Direction}

Porewater systems are characterized by multiple redox conditions and multiple metabolic processes and mineral reactions modify porewater carbonate chemistry [e.g., aerobic oxidation, sulfate reduction, denitrification, $\mathrm{CaCO}_{3}$ precipitation and dissolution (Krumins et al. 2013)]. Yet, few attempts have been made to fully characterize early diagenesis in seagrass sediments (Eldridge and Morse 2000; Hebert 2005; Hu 2007) and many openended questions remain to be resolved including quantifying the relative contribution from different biogeochemical processes to spatiotemporal variability of porewater DIC and TA. Although such a characterization is beyond the present study, a means to discern the net contribution from a combination of biogeochemical processes is by linear regression analysis of TA and DIC concentrations (Fig. 1; Deffeyes 1965; Moulin et al. 1985; Mackenzie and Andersson 2011; Drupp et al. 2016; Cyronak et al. 2018b). In the bottom waters at the two study locations, the non-salinity normalized TA:DIC slopes reflect the influences from a combination of these processes and mixing of porewater and the overlying seawater. In contrast, due to the restricted flow in the sediments, the porewater TA:DIC slopes are most strongly controlled by the prevailing porewater biogeochemical processes. This includes differential metabolic modification of DIC and TA dependent on the oxidation state, as well as DIC and TA production and consumption from $\mathrm{CaCO}_{3}$ dissolution and precipitation 
reactions, respectively (Morse and Mackenzie 1990; Burdige 2006). Based on studies from environments similar to Mangrove Bay, the observed slope close to 1 (0.85) in the porewaters was most likely a reflection of metabolically driven $\mathrm{CaCO}_{3}$ dissolution under aerobic conditions followed by sulfate reduction as the dominant process in the anaerobic parts of the sediments, potentially accompanied by $\mathrm{CaCO}_{3}$ precipitation (Moulin et al. 1985; Morse and Mackenzie 1990; Andersson et al. 2007; Mackenzie and Andersson 2011; Drupp et al. 2016). In Mission Bay, the high TA and DIC concentrations in combination with qualitative observations of $\mathrm{HgS}$ precipitation following $\mathrm{HgCl}_{2}$ poisoning and strong $\mathrm{H}_{2} \mathrm{~S}$ odors from porewater samples suggest that net sulfate reduction is a dominant anaerobic redox process (Holmer and Nielsen 1997). $\mathrm{CaCO}_{3}$ dissolution could also be important at this location, despite lower abundance of $\mathrm{CaCO}_{3}$ substrates, but further research will be needed to establish the relative influence of $\mathrm{CaCO}_{3}$ dissolution on porewater chemistry in these siliciclastic sediments.

Bioturbation and bioirrigation strongly affect the transport of solutes and redox conditions in porewaters (Aller 1982; Huettel and Gust 1992; Aller and Aller 1998). Several studies have found higher infaunal abundance in vegetated compared to unvegetated sediments (Stoner 1980; Edgar et al. 1994; Boström and Bonsdorff 1997; Fredriksen et al. 2010), suggesting that these additional infauna may have a greater effect on redox conditions and solute transport in sediments underlying seagrass beds. The role they play in modifying porewater carbonate chemistry within the rhizosphere, particularly in relation to ROL, should be investigated further.

Tides, currents and wave action can all induce a pressure gradient sufficient to drive advective transport in and out of the sediments, carrying solutes (e.g., DIC and TA) present in the porewater (Huettel and Webster 2001). If the sediment is readily flushed (i.e., advective forces dominate) a tidal signal could be represented in the temporal variability of porewater biogeochemistry, such as seen in Mangrove Bay (Ovalle et al. 1990; Jahnke et al. 2005; Zablocki et al. 2011; Drupp et al. 2016). Sediment properties and physical processes therefore need to be well-characterized across space and time in future assessments of porewater biogeochemistry, especially in vegetated sediments where small-scale spatial variability can be significant.

In conclusion, this study highlights the variable nature of porewater biogeochemistry on different spatial and temporal scales and examines the differences between seagrass-dominated sediment compared to unvegetated sediment in two distinctly different locations. These initial observations, utilizing comparable methods across sites, serve as a starting point for future studies aimed at elucidating the underlying mechanisms controlling the vertical and temporal variability in porewater carbonate chemistry in vegetated and unvegetated sediments. Seagrass seems to induce higher accumulation of DIC and TA in the porewaters compared to unvegetated sediments, possibly due to higher OM deposition in conjunction with oxygen loss from the roots, but further investigation is needed to decisively test this hypothesis in different seagrass systems. Future research should also focus on constraining the interaction between physicochemical setting and early diagenetic processes and its effect on spatiotemporal variability of carbonate chemistry. As illustrated here, environmental differences such as tidal regime and sediment characteristics can affect the short-term variability in carbonate chemistry, and changes in the water column can influence the sediment porewater chemistry in variable ways. The demonstrated connectivity between sediment and overlying water column implies that fluxes of DIC and TA between these waters can be significant. Thus, these features need to be considered in biogeochemical models and future assessments of coastal carbon cycling. 
Acknowledgements Open access funding provided by Lund University. This study was conducted in part at the Kendall-Frost Mission Bay Marsh Reserve of the University of California National Reserve System (UCNRS). Funding was received from National Science Foundation OCE 12-55042 (AJA). The constructive reviews of David J. Burdige and two anonymous referees are gratefully acknowledged.

Funding Funding was received from National Science Foundation OCE 12-55042 (AJA).

\section{Compliance with Ethical Standards}

Conflict of interest The authors declare that they have no conflict of interest.

Open Access This article is licensed under a Creative Commons Attribution 4.0 International License, which permits use, sharing, adaptation, distribution and reproduction in any medium or format, as long as you give appropriate credit to the original author(s) and the source, provide a link to the Creative Commons licence, and indicate if changes were made. The images or other third party material in this article are included in the article's Creative Commons licence, unless indicated otherwise in a credit line to the material. If material is not included in the article's Creative Commons licence and your intended use is not permitted by statutory regulation or exceeds the permitted use, you will need to obtain permission directly from the copyright holder. To view a copy of this licence, visit http://creativecommons.org/licenses/by/4.0/.

\section{References}

Aller RC (1982) Carbonate dissolution in nearshore terrigenous muds: the role of physical and biological reworking. J Geol 90:79-95. https://doi.org/10.1086/628652

Aller RC, Aller JY (1998) The effect of biogenic irrigation intensity and solute exchange on diagenetic reaction rates in marine sediments. J Mar Res 56:905-936. https://doi.org/10.1357/002224098321667413

Andersson AJ, Bates NR, Mackenzie FT (2007) Dissolution of carbonate sediments under rising $\mathrm{pCO}_{2}$ and ocean acidification: observations from Devil's Hole, Bermuda. Aquat Geochem 13:237-264. https:// doi.org/10.1007/s10498-007-9018-8

Andersson AJ, Yeakel KL, Bates NR, de Putron SJ (2014) Partial offsets in ocean acidification from changing coral reef biogeochemistry. Nat Clim Chang 4:56-61. https://doi.org/10.1038/nclimate2050

Barron C, Duarte CM, Frankignoulle M, Borges AV (2006) Organic carbon metabolism and carbonate dynamics in a Mediterranean seagrass (Posidonia oceanica) meadow. Estuaries Coasts 29:417-426. https://doi.org/10.1007/BF02784990

Bauer JE, Cai WJ, Raymond PA, Bianchi TS, Hopkinson CS, Regnier PAG (2013) The changing carbon cycle of the coastal ocean. Nature 504:61-70. https://doi.org/10.1038/nature12857

Bennett RH et al (1990) In situ porosity and permeability of selected carbonate sediment: Great Bahama Bank Part 1: measurements. Mar Georesour Geotechnol 9:1-28. https://doi.org/10.1080/1064119900 9388227

Blaabjerg V, Mouritsen KN, Finster K (1998) Diel cycles of sulphate reduction rates in sediments of a Zostera marina bed (Denmark). Aquat Microb Ecol 15:97-102. https://doi.org/10.3354/ame015097

Blott SJ, Pye K (2001) GRADISTAT: a grain size distribution and statistics package for the analysis of unconsolidated sediments. Earth Surf Process Landf 26:1237-1248

Bockmon EE, Dickson AG (2014) A seawater filtration method suitable for total dissolved inorganic carbon and $\mathrm{pH}$ analyses. Limnol Oceanogr: Methods 12:191-195. https://doi.org/10.4319/lom.2014.12.191

Borum J, Sand-Jensen K, Binzer T, Pedersen O, Greve TM (2007) Oxygen movement in seagrasses. In: Larkum AWD, Orth RJ, Duarte CM (eds) Seagrasses: biology, ecology and conservation. Springer, Dordrecht, pp 255-270. https://doi.org/10.1007/978-1-4020-2983-7

Boström C, Bonsdorff E (1997) Community structure and spatial variation of benthic invertebrates associated with Zostera marina (L.) beds in the northern Baltic Sea. J Sea Res 37:153-166. https://doi. org/10.1016/S1385-1101(96)00007-X

Bouillon S et al (2007) Importance of intertidal sediment processes and porewater exchange on the water column biogeochemistry in a pristine mangrove creek (Ras Dege, Tanzania). Biogeosci Discuss 4:317-348 
Brodersen KE, Koren K, Lichtenberg M, Kühl M (2016) Nanoparticle-based measurements of $\mathrm{pH}^{\mathrm{H}}$ and $\mathrm{O}_{2}$ dynamics in the rhizosphere of Zostera marina L.: effects of temperature elevation and light-dark transitions. Plant, Cell Environ 39:1619-1630. https://doi.org/10.1111/pce.12740

Brodersen KE, Siboni N, Nielsen D, Pernice M, Ralph P, Seymour J, Kühl M (2018) Seagrass rhizosphere microenvironment alters plant-associated microbial community composition. Environ Microbiol. https ://doi.org/10.1111/1462-2920.14245

Burdige DJ (2006) Geochemistry of marine sediments. Princeton University Press, Princeton

Burdige DJ, Zimmerman RC (2002) Impact of sea grass density on carbonate dissolution in Bahamian sediments. Limnol Oceanogr 47:1751-1763. https://doi.org/10.4319/lo.2002.47.6.1751

Burdige DJ, Zimmerman RC, Hu X (2008) Rates of carbonate dissolution in permeable sediments estimated from pore-water profiles: the role of sea grasses. Limnol Oceanogr 53:549-565. https://doi. org/10.4319/lo.2008.53.2.0549

Caffrey J, Kemp W (1991) Seasonal and spatial patterns of oxygen production, respiration and root-rhizome release in Potamogeton perfoliatus L. and Zostera marina L. Aquat Bot 40:109-128. https://doi. org/10.1016/0304-3770(91)90090-R

Camp EF, Suggett DJ, Gendron G, Jompa J, Manfrino C, Smith DJ (2016) Mangrove and seagrass beds provide different biogeochemical services for corals threatened by climate change. Front Mar Sci. https:// doi.org/10.3389/fmars.2016.00052

Cyronak T et al (2018a) Short-term spatial and temporal carbonate chemistry variability in two contrasting seagrass meadows: implications for $\mathrm{pH}$ buffering capacities. Estuaries Coasts. https://doi.org/10.1007/ s12237-017-0356-5

Cyronak T et al (2018b) Taking the metabolic pulse of the world's coral reefs. PLoS ONE 13:e0190872. https://doi.org/10.1371/journal.pone.0190872

Deborde $\mathrm{J}$ et al (2008) Role of tidal pumping on nutrient cycling in a temperate lagoon (Arcachon Bay, France). Mar Chem 109:98-114. https://doi.org/10.1016/j.marchem.2007.12.007

Deffeyes KS (1965) Carbonate equilibria: a graphic and algebraic approach. Limnol Oceanogr 10:412-426. https://doi.org/10.4319/lo.1965.10.3.0412

Delgard ML et al (2016) Biogeochemistry of dissolved inorganic carbon and nutrients in seagrass (Zostera noltei) sediments at high and low biomass. Estuar Coast Shelf Sci 179:12-22. https://doi.org/10.1016/j. ecss.2016.01.012

DelValls T, Dickson A (1998) The pH of buffers based on 2-amino-2-hydroxymethyl-1, 3-propanediol ('tris') in synthetic sea water. Deep Sea Res Part I 45:1541-1554. https://doi.org/10.1016/S0967 $-0637(98) 00019-3$

Dickson AG, Goyet C (1994) Handbook of methods for the analysis of the various parameters of the carbon dioxide system in sea water, version 2. Oak Ridge National Lab., TN, USA

Dickson AG, Sabine CL, Christian JRE (2007) Guide to best practices for ocean $\mathrm{CO}_{2}$ measurements. PICES Special Publ 3:191

Drupp PS, De Carlo EH, Mackenzie FT (2016) Porewater $\mathrm{CO}_{2}$-carbonic acid system chemistry in permeable carbonate reef sands. Mar Chem 185:48-64. https://doi.org/10.1016/j.marchem.2016.04.004

Duarte CM, Middelburg JJ, Caraco N (2005) Major role of marine vegetation on the oceanic carbon cycle. Biogeosciences 2:1-8. https://doi.org/10.5194/bg-2-1-2005

Edgar G, Shaw C, Watsona G, Hammond L (1994) Comparisons of species richness, size-structure and production of benthos in vegetated and unvegetated habitats in Western Port, Victoria. J Exp Mar Biol Ecol 176:201-226. https://doi.org/10.1016/0022-0981(94)90185-6

Eldridge PM, Morse JW (2000) A diagenetic model for sediment-seagrass interactions. Mar Chem 70:89_ 103. https://doi.org/10.1016/S0304-4203(00)00018-9

Elliott DT, Kaufmann RS (2007) Spatial and temporal variability of mesozooplankton and tintinnid ciliates in a seasonally hypersaline estuary. Estuaries Coasts 30:418-430. https://doi.org/10.1007/BF02819388

Falter JL, Sansone FJ (2000) Shallow pore water sampling in reef sediments. Coral Reefs 19:93-97. https:// doi.org/10.1007/s003380050233

Fourqurean JW et al (2012) Seagrass ecosystems as a globally significant carbon stock. Nat Geosci 5:505509. https://doi.org/10.1038/ngeo1477

Frederiksen MS, Glud RN (2006) Oxygen dynamics in the rhizosphere of Zostera marina: a two-dimensional planar optode study. Limnol Oceanogr 51:1072-1083. https://doi.org/10.4319/lo.2006.51.2.1072

Fredriksen S, De Backer A, Boström C, Christie H (2010) Infauna from Zostera marina L. meadows in Norway. Differences in vegetated and unvegetated areas. Mar Biol Res 6:189-200. https://doi. org/10.1080/17451000903042461

Goyet C, Bradshaw AL, Brewer PG (1991) The carbonate system in the Black sea. Deep-Sea Res Part a-Oceanogr Res Pap 38:S1049-S1068. https://doi.org/10.1016/S0198-0149(10)80023-8 
Gran G (1952) Determination of the equivalence point in potentiometric titrations. Part II. Analyst 77:661-671

Greve TM, Borum J, Pedersen O (2003) Meristematic oxygen variability in eelgrass (Zostera marina). Limnol Oceanogr 48:210-216. https://doi.org/10.4319/lo.2003.48.1.0210

Hebert AB (2005) Diagenesis in seagrass vegetated sediments: biogeochemical processes on diurnal time scales. Ph.D. thesis, Texas A\&M University

Hendriks IE et al (2014) Photosynthetic activity buffers ocean acidification in seagrass meadows. Biogeosciences 11:333-346. https://doi.org/10.5194/bg-11-333-2014

Hines ME, Lyons WB (1982) Biogeochemistry of nearshore Bermuda sediments. I. Sulfate reduction rates and nutrient generation. Mar Ecol-Prog Ser, 87-94

Holmer M, Nielsen SL (1997) Sediment sulfur dynamics related to biomass-density patterns in Zostera marina (eelgrass) beds. Mar Ecol-Prog Ser 146:163-171

Howard J et al (2017) Clarifying the role of coastal and marine systems in climate mitigation. Front Ecol Environ 15:42-50. https://doi.org/10.1002/fee.1451

Hu X (2007) Seagrass-mediated carbonate dissolution and early diagenesis in Bahamas Bank sediments. Ph.D. thesis, Old Dominion University

Huettel M, Gust G (1992) Solute release mechanisms from confined sediment cores in stirred benthic chambers and flume flows. Mar Ecol-Prog Ser, 187-197

Huettel M, Webster IT (2001) Porewater flow in permeable sediments. In: Boudreau BP, Jørgensen BB (eds) The benthic boundary layer: transport processes and biogeochemistry. Oxford University Press, New York, pp 144-179

Ingemann Jensen S, Kühl M, Glud RN, Jørgensen LB, Priemé A (2005) Oxic microzones and radial oxygen loss from roots of Zostera marina. Mar Ecol-Prog Sers Online 293:49-58

Invers O, Zimmerman RC, Alberte RS, Pérez M, Romero J (2001) Inorganic carbon sources for seagrass photosynthesis: an experimental evaluation of bicarbonate use in species inhabiting temperate waters. $\mathrm{J}$ Exp Mar Biol Ecol 265:203-217. https://doi.org/10.1016/S0022-0981(01)00332-X

Jahnke RA, Jahnke DB (2004) Calcium carbonate dissolution in deep sea sediments: reconciling microelectrode, pore water and benthic flux chamber results. Geochim Cosmochim Acta 68:47-59. https://doi. org/10.1016/S0016-7037(03)00260-6

Jahnke R, Richards M, Nelson J, Robertson C, Rao A, Jahnke D (2005) Organic matter remineralization and porewater exchange rates in permeable South Atlantic Bight continental shelf sediments. Cont Shelf Res 25:1433-1452. https://doi.org/10.1016/j.csr.2005.04.002

Johnson MR, Williams SL, Lieberman CH, Solbak A (2003) Changes in the abundance of the seagrasses Zostera marina L. (eelgrass) and Ruppia maritima L. (widgeongrass) in San Diego, California, following an El Nino event. Estuaries 26:106-115. https://doi.org/10.1007/bf02691698

Jones WB, Cifuentes LA, Kaldy JE (2003) Stable carbon isotope evidence for coupling between sedimentary bacteria and seagrasses in a sub-tropical lagoon. Mar Ecol-Prog Ser 255:15-25. https://doi. org/10.3354/meps 255015

Jourabchi P, Van Cappellen P, Regnier P (2005) Quantitative interpretation of pH distributions in aquatic sediments: a reaction-transport modeling approach. Am J Sci 305:919-956

Knap A et al (1997) BATS Methods manual, version 4. JGOFS Planning Office, Woods Hole

Krumins V, Gehlen M, Arndt S, Van Cappellen P, Regnier P (2013) Dissolved inorganic carbon and alkalinity fluxes from coastal marine sediments: model estimates for different shelf environments and sensitivity to global change. Biogeosciences 10:371-398. https://doi.org/10.5194/bg-10-371-2013

Ku T, Walter L, Coleman M, Blake R, Martini A (1999) Coupling between sulfur recycling and syndepositional carbonate dissolution: evidence from oxygen and sulfur isotope composition of pore water sulfate, South Florida Platform, USA. Geochim Cosmochim Acta 63:2529-2546

Largier J, Hollibaugh JT, Smith S (1997) Seasonally hypersaline estuaries in Mediterranean-climate regions. Estuar Coast Shelf Sci 45:789-797. https://doi.org/10.1006/ecss.1997.0279

Lee K-S, Dunton KH (2000) Diurnal changes in pore water sulfide concentrations in the seagrass Thalassia testudinum beds: the effects of seagrasses on sulfide dynamics. J Exp Mar Biol Ecol 255:201-214. https://doi.org/10.1016/S0022-0981(00)00300-2

Lessin G et al (2018) Modelling marine sediment biogeochemistry: current knowledge gaps, challenges and some methodological advice for advancement. Front Mar Sci 5:19. https://doi.org/10.3389/fmars .2018 .00019

Levin LA (1984) Life history and dispersal patterns in a dense infaunal polychaete assemblage: community structure and response to disturbance. Ecology 65:1185-1200

Lewis E, Wallace D (1998) Program developed for $\mathrm{CO}_{2}$ system calculations. Carbon Dioxide Information Analysis Center, managed by Lockheed Martin Energy Research Corporation for the US Department of Energy Tennessee 
Long MH, Rheuban JE, Berg P, Zieman JC (2012) A comparison and correction of light intensity loggers to photosynthetically active radiation sensors. Limnol Oceanogr: Methods 10:416-424. https://doi. org/10.4319/lom.2012.10.416

Lueker TJ, Dickson AG, Keeling CD (2000) Ocean pCO(2) calculated from dissolved inorganic carbon, alkalinity, and equations for $\mathrm{K}-1$ and $\mathrm{K}-2$ : validation based on laboratory measurements of $\mathrm{CO}_{2}$ in gas and seawater at equilibrium. Mar Chem 70:105-119. https://doi.org/10.1016/s0304 -4203(00)00022-0

Lyons W, Wilson K, Armstrong P, Smith G, Gaudette H (1980) Trace-metal pore water geochemistry of nearshore bermuda carbonate sediments. Oceanol Acta 3:363-367

Mackenzie FT, Andersson AJ (2011) Biological control on diagenesis: influence of bacteria and relevance to ocean acidification. In: Reitner J, Thiel V (eds) Encyclopedia of geobiology. Springer, Dordrecht, pp 137-143. https://doi.org/10.1007/978-1-4020-9212-1_73

Mazarrasa I et al (2015) Seagrass meadows as a globally significant carbonate reservoir. Biogeosciences 12:4993-5003. https://doi.org/10.5194/bg-12-4993-2015

Menne MJ, Durre I, Vose RS, Gleason BE, Houston TG (2012) An overview of the global historical climatology network-daily database. J Atmos Ocean Technol 29:897-910. https://doi.org/10.1175/ JTECH-D-11-00103.1

Middelburg JJ (2018) Reviews and syntheses: to the bottom of carbon processing at the seafloor. Biogeosciences 15:413-427. https://doi.org/10.5194/bg-15-413-2018

Migné A, Davoult D, Spilmont N, Ouisse V, Boucher G (2016) Spatial and temporal variability of $\mathrm{CO}_{2}$ fluxes at the sediment-air interface in a tidal flat of a temperate lagoon (Arcachon Bay, France). J Sea Res 109:13-19. https://doi.org/10.1016/j.seares.2016.01.003

Miyajima T, Koike I, Yamano H, Iizumi H (1998) Accumulation and transport of seagrass-derived organic matter in reef flat sediment of Green Island, Great Barrier Reef. Mar Ecol-Prog Ser 175:251-259

Morse JW, Mackenzie FT (1990) Geochemistry of sedimentary carbonates, vol 48. Elsevier, Amsterdam

Moulin E, Jordens A, Wollast R (1985) Influence of the aerobic bacterial respiration on the early dissolution of carbonates in coastal sediments. In: Proceedings progress in Belgium Oceanographic Research, Brussels

Mucci A, Sundby B, Gehlen M, Arakaki T, Zhong S, Silverberg N (2000) The fate of carbon in continental shelf sediments of eastern Canada: a case study. Deep Sea Res Part II 47:733-760

Nellemann C, Corcoran E, Duarte C, Valdés L, De Young C, Fonseca L, Grimsditch G (2009) Blue Carbon: a rapid response assessment. United Nations Environment Programme, GRID-Arendal 80

Obaza A, Hoffman R, Clausing R (2015) Long-term stability of eelgrass fish assemblages in two highly developed coastal estuaries. Fisheries Manag Ecol 22:224-238. https://doi.org/10.1111/fme.12119

Ovalle A, Rezende C, Lacerda L, Silva C (1990) Factors affecting the hydrochemistry of a mangrove tidal creek, Sepetiba Bay, Brazil. Estuar Coast Shelf Sci 31:639-650. https://doi.org/10.1016/02727714(90)90017-L

Pacella SR, Brown CA, Waldbusser GG, Labiosa RG, Hales B (2018) Seagrass habitat metabolism increases short-term extremes and long-term offset of $\mathrm{CO}_{2}$ under future ocean acidification. Proc Natl Acad Sci 115:3870-3875. https://doi.org/10.1073/pnas.1703445115

Rao AMF, Malkin SY, Montserrat F, Meysman FJR (2014) Alkalinity production in intertidal sands intensified by lugworm bioirrigation. Estuar Coast Shelf Sci 148:36-47. https://doi.org/10.1016/j. ecss.2014.06.006

Rassmann J, Lansard B, Pozzato L, Rabouille C (2016) Carbonate chemistry in sediment porewaters of the Rhône River delta driven by early diagenesis (northwestern Mediterranean). Biogeosciences 13:5379. https://doi.org/10.5194/bg-13-5379-2016

Rassmann $\mathbf{J}$ et al (2018) Impact of ocean acidification on the biogeochemistry and meiofaunal assemblage of carbonate-rich sediments: results from core incubations (Bay of Villefranche, NW Mediterranean Sea). Mar Chem 203:102-119. https://doi.org/10.1016/j.marchem.2018.05.006

Sand-Jensen K, Prahl C, Stokholm H (1982) Oxygen release from roots of submerged aquatic macrophytes. Oikos, 349-354

Santos IR, Eyre BD, Huettel M (2012) The driving forces of porewater and groundwater flow in permeable coastal sediments: a review. Estuar Coast Shelf Sci 98:1-15. https://doi.org/10.1016/j.ecss.2011.10.024

Semesi IS, Beer S, Björk M (2009) Seagrass photosynthesis controls rates of calcification and photosynthesis of calcareous macroalgae in a tropical seagrass meadow. Mar Ecol-Prog Ser 382:41-47. https ://doi.org/10.3354/meps07973

Shum K (1992) Wave-induced advective transport below a rippled water-sediment interface. J Geophys Res: Oceans 97:789-808. https://doi.org/10.1029/91JC02101 
Sippo JZ, Maher DT, Tait DR, Holloway C, Santos IR (2016) Are mangroves drivers or buffers of coastal acidification? Insights from alkalinity and dissolved inorganic carbon export estimates across a latitudinal transect. Global Biogeochem Cycles 30:753-766. https://doi.org/10.1002/2015gb005324

Smith RD, Dennison WC, Alberte RS (1984) Role of seagrass photosynthesis in root aerobic processes. Plant Physiol 74:1055-1058. https://doi.org/10.1104/pp.74.4.1055

Stoner AW (1980) The role of seagrass biomass in the organization of benthic macrofaunal assemblages. Bull Mar Sci 30:537-551

Taillardat $\mathrm{P}$ et al (2018) Carbon dynamics and inconstant porewater input in a mangrove tidal creek over contrasting seasons and tidal amplitudes. Geochim Cosmochim Acta 237:32-48. https://doi. org/10.1016/j.gca.2018.06.012

Tait DR, Maher DT, Macklin PA, Santos IR (2016) Mangrove pore water exchange across a latitudinal gradient. Geophys Res Lett 43:3334-3341. https://doi.org/10.1002/2016GL068289

Talley DM, Talley TS, Blanco A (2015) Insights into the establishment of the Manila clam on a tidal flat at the southern end of an introduced range in Southern California, USA. PLoS ONE 10:13. https://doi. org/10.1371/journal.pone.0118891

Unsworth RKF, Collier CJ, Henderson GM, McKenzie LJ (2012) Tropical seagrass meadows modify seawater carbon chemistry: implications for coral reefs impacted by ocean acidification. Environ Res Lett 7:024026. https://doi.org/10.1088/1748-9326/7/2/024026

Winkel A, Borum J (2009) Use of sediment $\mathrm{CO}_{2}$ by submersed rooted plants. Ann Bot 103:1015-1023. https://doi.org/10.1093/aob/mcp036

Zablocki JA, Andersson AJ, Bates NR (2011) Diel aquatic $\mathrm{CO}_{2}$ system dynamics of a Bermudian mangrove environment. Aquat Geochem 17:841. https://doi.org/10.1007/s10498-011-9142-3

Zeebe RE, Wolf-Gladrow DA (2001) $\mathrm{CO}_{2}$ in seawater: equilibrium, kinetics, isotopes vol. 65. Gulf Professional Publishing

Publisher's Note Springer Nature remains neutral with regard to jurisdictional claims in published maps and institutional affiliations.

\section{Affiliations}

\section{Theodor Kindeberg ${ }^{1,2,3}$ - Nicholas R. Bates ${ }^{4,5}$ - Travis A. Courtney ${ }^{1}$ Tyler Cyronak ${ }^{1,7}$. Alyssa Griffin ${ }^{1} \cdot$ Fred T. Mackenzie ${ }^{6} \cdot$ May-Linn Paulsen ${ }^{1}$. Andreas J. Andersson ${ }^{1}$}

1 Scripps Institution of Oceanography, University of California San Diego, 9500 Gilman Drive, La Jolla, CA 92093-0244, USA

2 Centre for Environmental and Climate Research, Lund University, Sölvegatan 37, 22362 Lund, Sweden

3 Present Address: Department of Biology, Lund University, Sölvegatan 37, 22362 Lund, Sweden

4 Bermuda Institute of Ocean Sciences, 17 Biological Station, St. George's GE01, Bermuda

5 Ocean and Earth Science, National Oceanography Centre Southampton, University of Southampton, Southampton SO14 3ZH, UK

6 Department of Oceanography, University of Hawaii, 1000 Pope Rd., Honolulu, HI 96822, USA

7 Department of Marine and Environmental Sciences, Halmos College of Natural Sciences and Oceanography, Nova Southeastern University, 8000 North Ocean Drive, Dania Beach, FL 33004, USA 